\title{
REVIEW
}

\section{Insights on Medical Nutrition Therapy for Type 2 Diabetes Mellitus: An Indian Perspective}

\author{
Vijay Viswanathan · Dharini Krishnan · Sanjay Kalra • \\ Rajeev Chawla $\cdot$ Mangesh Tiwaskar · Banshi Saboo · Manash Baruah • \\ Subhankar Chowdhury · B. M. Makkar · Shalini Jaggi
}

Received: November 15, 2018 / Published online: February 7, 2019

(C) The Author(s) 2019

\begin{abstract}
It is critical to integrate medical nutrition therapy (MNT) provided by a registered dietician (RD) into primary care of type 2 diabetes mellitus (T2DM). This is necessary to achieve the goals of improving overall metabolic measures beyond calorie restriction and weight loss. Misconceptions about nutrition in T2DM add to the challenges of executing MNT in a culturally sensitive population. The current review provides insights into MNT for the
\end{abstract}

Enhanced Digital Features To view enhanced digital features for this article go to https://doi.org/10.6084/ m9.figshare.7558802.

V. Viswanathan

M.V. Hospital for Diabetes and Prof.

M. Viswanathan Diabetes Research Centre (WHO

Collaborating Centre for Research, Education and

Training in Diabetes), Chennai, Tamil Nadu, India

D. Krishnan

Wellness Clinic, Teynampet, Chennai, India

S. Kalra $(\bowtie)$

Bharti Research Institute of Diabetes \&

Endocrinology (BRIDE), Karnal, Haryana, India

e-mail: brideknl@gmail.com

R. Chawla

North Delhi Diabetic Centre, New Delhi, India

M. Tiwaskar

Shilpa Medical Research Centre, Mumbai,

Maharashtra, India prevention and management of T2DM in India, based on both evidence and experience. It revisits historical Indian studies and provides information on appropriate dietary intake of carbohydrates $(60-70 \%)$, proteins $(\sim 20 \%)$ and fats $(10 \%)$ that will be acceptable and beneficial in an Indian T2DM population. It discusses nuances of types of carbohydrates and fats and explains associations of increased dietary fiber intake, balanced intake of low and high glycemic index foods and substitution of saturated fats with plant-based polyunsaturated fats in improving outcomes of T2DM and attenuating risk factors. The article also deliberates upon special patient populations with comorbid conditions and diseases and

B. Saboo

Dia Care-Diabetes and Hormone Centre,

Ahmedabad, Gujarat, India

M. Baruah

Excelcare Hospitals, Guwahati, Assam, India

S. Chowdhury

Institute of Postgraduate Medical Education and

Research/SSKM Hospital, Kolkata, India

B. M. Makkar

Diabetes and Obesity Center, New Delhi, India

S. Jaggi

Dr. Mohan's Diabetes Specialties Centre, New Delhi, India 
the necessary adjustments needed in their nutritional care. It outlines a step-wise approach to MNT involving a careful interplay of nutrition assessment, diagnosis, individualization and patient counseling. Overall, the success of MNT relies on providing accurate, acceptable and appropriate dietary choices for continued patient adherence. Collaborative efforts from diabetologists, endocrinologists, internists and RDs are required to prioritize and implement MNT in diabetes practice in India.

Funding: Signutra Inc.

Keywords: Diabetes; India; Medical nutrition therapy; Registered dietician; Type 2 diabetes mellitus

\section{INTRODUCTION}

Globally, 425 million individuals were living with diabetes in 2017, and the numbers are expected to rise to 693 million by 2045 [1]. India, with over 72 million people with type 2 diabetes mellitus (T2DM) in 2017, was reported to have the second largest population of individuals living with T2DM [2]. The rapidly changing dynamics of the T2DM pandemic in low- and middle-income countries correlates with the dramatic transition to urbanization; an unhealthy modern diet and low activity patterns are regarded as major drivers [3]. Evidence from several regional epidemiologic studies suggests that urban locales in India harbor more people with T2DM than the rural areas [4-6]. A recent study supported by the Indian Council for Medical Research-India Diabetes (ICMR-INDIAB) estimates the prevalence of T2DM in India to be 7.3\% (95\% CI 7.0-7.5) [7]. Replacements of traditional Indian meals and recipes that include legumes, coarse cereals, whole grains, fruits and vegetables with modern foods comprising refined carbohydrates, added sugars and high intake of fats have occurred concurrently with the rising trend in diabetes $[3,8-10]$. In addition, the exponential expansion of fast food establishments and supermarkets has allowed easy access to westernized foods. Excessive consumption of sugar and jaggery-laden sweets that have significant cultural and religious relevance in India is an inherent part of the common Indian diet and has contributed to the high prevalence of metabolic disturbances in the Indian population [11].

Anecdotal dietary restrictions and inadvertent exclusion of beneficial dietary ingredients have also been reported in Indian patients with diabetes. A cross-sectional study from an urban healthcare center in Puducherry identified a number of misbeliefs that included complete removal of dietary carbohydrates, inclusion of bitter foods that potentially lower blood glucose levels and disregard of lifestyle modifications [12]. Complete exclusion of dietary fruits, milk and tubers because of the misconception that all sweet substances are harmful was observed among patients with diabetes attending clinics in North India [13]. These misbeliefs reflect the overall community perspective and are often major reasons for deliberate ignorance concerning dietary guidance and barriers to pharmacologic treatment attempts.

An appropriate lifestyle and dietary changes have proven to be effective for the prevention and management of diabetes mellitus [14-16]. Medical nutrition therapy (MNT) is an essential component of diabetes management that comprises counseling and recommendations for dietary intake and nutrition goals by a registered dietician (RD) or a nutrition expert to optimize metabolic control and maximize treatment outcomes. It includes designing of diet plans individualized per patient needs along with regular monitoring by the $\mathrm{RD}$ and diabetologist [17-19]. Thus, MNT involves integrated efforts from the RD and diabetologist along with patient self-management and conscientiousness. Clinical evidence suggests that patients with diabetes receiving MNT achieve a $1-2 \%$ decrease in HbA1c, which is comparable to the outcomes of antidiabetic treatment, along with reductions in healthcare costs, attributable to improvements in overall health outcomes and quality of life [20-25]. This article is based on previously conducted studies and does not contain any studies with human participants or animals performed by any of the authors.

\section{MEDICAL NUTRITION THERAPY IN INDIA}

International collaborative groups for diabetes management have provided recommendations 
for MNT as an attempt to reform the course of the adverse nutritional transition [17, 26, 27]. India, with its rich medical and health legacy, chronicles dietary principles and diet-based therapies for the management of T2DM. However, over the years, these concepts have been confused because of the plethora of studies and multiple recommendation guidelines catering to different regions and populations, a general unawareness among healthcare experts and a dearth of nutrition professionals familiar with MNT for T2DM. From an Indian perspective, adjustments in diet should involve a careful consideration of regional influences on lifestyle, culinary diversity, economic issues and local agricultural considerations to improve acceptance among individuals with T2DM [28]. The MNT should therefore involve designing signature diet plans that are not only medically appropriate, but also patient-centric. This consensus brings together practicing diabetologists and an RD from India to provide an evidence-based nutritional guideline for application of MNT in the prevention and management of diabetes and associated comorbidities. This article does not contain any studies with human participants or animals performed by any of the authors.

\section{AVAILABLE RECOMMENDATIONS FROM WORKING GROUPS}

Working groups from India such as the Research Society for the Study of Diabetes in India (RSSDI) and Indian Council of Medical Research (ICMR) have used nutritional principles while framing treatment recommendations for diabetes. The RSSDI endorses comprehensive lifestyle measures that include implementation of MNT for achieving an optimal glycemic and lipemic index and the overall well-being of the patient $[29,30]$. The RSSDI recommends diet therapies that are personalized to the individual health profile, cultural and economic background, include access to healthy foods and are generally in agreement with the nutrition recommendations of the American Diabetes Association (Table 1) [30-32]. The group recommends a diet including high carbohydrate (up to 45-65\%), predominantly low glycemic index (GI) sources, low fat and adequate protein (up to 15\%). The preferred sources of carbohydrates are legumes, whole fruits and vegetables that contain unrefined carbohydrates and high fiber content. The diet plan recommends substitution of saturated fats and trans fats with monounsaturated fatty acids (MUFA) in patients with impaired glucose tolerance (IGT), diabetes and obesity. A low-carbohydrate ketogenic diet is also suggested by the RSSDI and is preferred over a low-calorie diet. However, the experts advise that effects on the lipid profile should be monitored and adjustments should be made based on individual characteristics [30, 33, 34]. Addition of an insulinemic cereal-pulse mixture is recommended as part of a fiber-rich proteinaceous diet. The staple Indian diet (dal, roti, rice and curry) is regarded as a mixed yet balanced diet comprising carbohydrates of varying GI, proteins and fats that ensure satiety and adequate calories. As a general guidance, the RSSDI does not recommend intake of alcohol, tobacco, refined sugar or processed, refined and fried foods.

Dietary recommendations for patients with diabetes from the ICMR concur with those from the RSSDI and emphasize lifestyle-adjusted changes [35]. The ICMR recommends adoption of a diet containing carbohydrates (55-60\%) including cereals, mixed coarse grains, whole pulses, salads and soybeans; proteins (10-15\%) from vegetable sources, low fat milk and milk products, fish and lean meat; fats (20-25\%) comprising $<7 \%$ of saturated fats and the major proportion from MUFA and polyunsaturated fatty acids (PUFA). Other recommendations include consumption of moderate amounts of whole fruits and fiber-rich foods, restricted intake of salt and artificial sweeteners, and avoidance of alcohol and tobacco [35].

\section{MEDICAL NUTRITION THERAPY IN PREDIABETES}

The RSSDI categorizes early diabetes or prediabetes as a condition diagnosed by IGT [2-h plasma glucose in the 75-g oral glucose tolerance test (OGTT): 140-199 mg/dl] and 


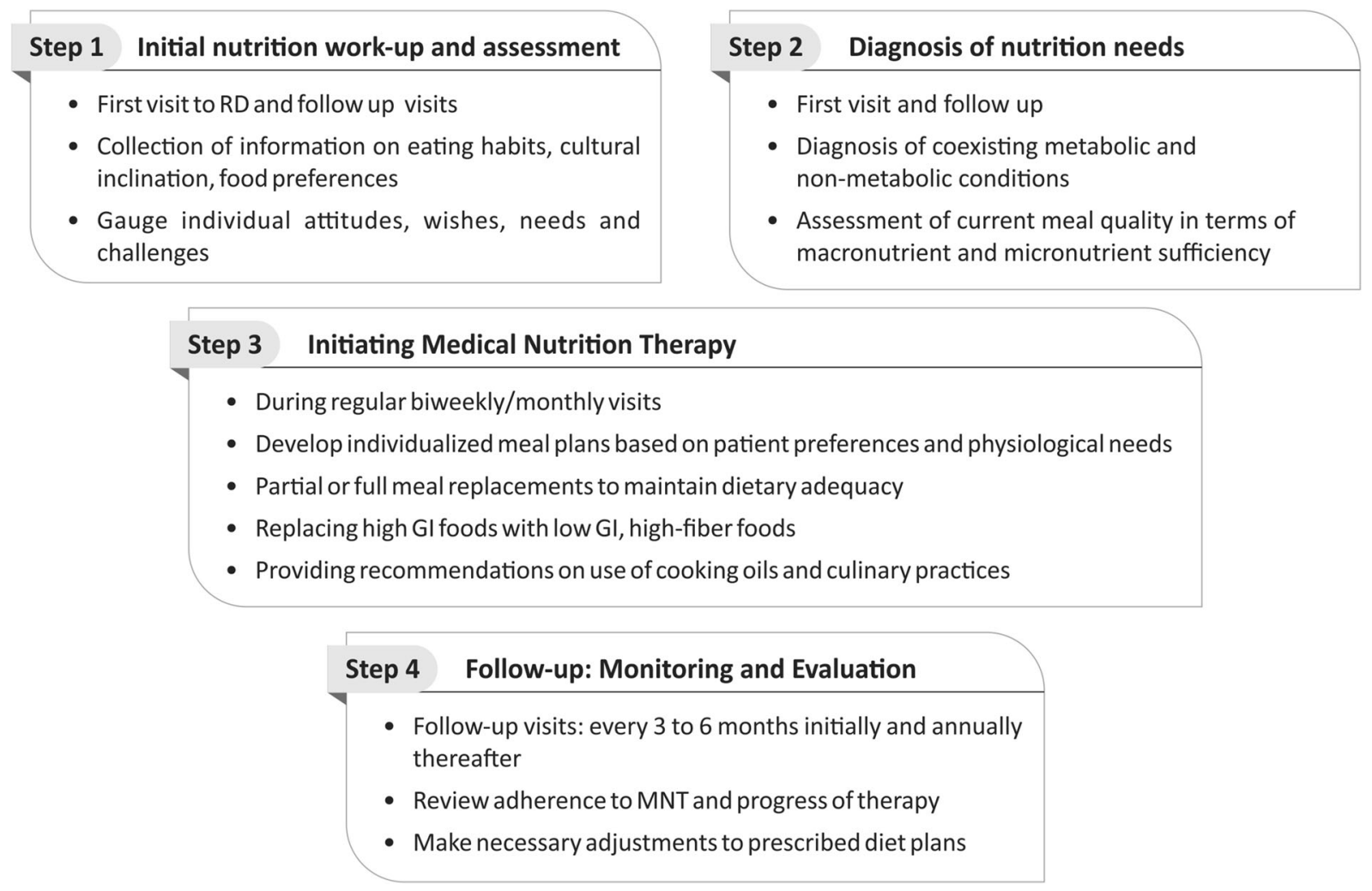

Fig. 1 Step-wise approach for implementation of MNT. GI glycemic index, $M N T$ medical nutrition therapy, $R D$ registered dietician

impaired fasting glucose [fasting plasma glucose (FPG) between 110 to $125 \mathrm{mg} / \mathrm{dl}$ or glycosylated hemoglobin (HbA1c) of 5.7-6.4\%] [29, 30]. Despite a lower body mass index (BMI), Asian Indians exhibit a higher prevalence of IGT (age standardized prevalence 14\%) and a greater tendency for progression of IGT to T2DM compared with Western populations [36, 37].

MNT plays an integral role in decelerating the conversion of prediabetes to diabetes and is a cost-effective measure in improving outcomes and quality of life in patients with prediabetes [38]. Dietary strategies have been successfully employed for the prevention of diabetes in several landmark studies such as the Finnish Diabetes Prevention Study (DPS), the Diabetes Prevention Programme (DPP) and the Nurses' Health Study (Table 2) [39-42]. Both programs adopted dietary strategies individualized to the patient's needs, choices and body weight, with focus on controlling fat intake and maintaining a standard calorie intake, and reported a reduced risk of diabetes in participating individuals $[15,40]$. The DPP study concluded that the incidence of T2DM can be lowered by $58 \%$ using lifestyle-structured intervention programs. In the 10-year follow-up study (DPP Outcome Study), the incidence of T2DM was reduced by $34 \%$ in the lifestyle intervention group and $18 \%$ in the metformin group compared with the placebo group [43].

In a study involving native Asian Indian participants with IGT, lifestyle modification with or without lower dose of metformin $(500 \mathrm{mg})$ was effective in lowering the conversion of IGT to T2DM [44]. In another 2-year prospective study conducted in Indian men with IGT, healthy lifestyle adjustments comprising a calorie-restricted diet were associated with a decreased rate of incident diabetes [45]. Adherence to a balanced diet and regular physical activity improved insulin sensitivity and beta cell preservation [45]. Favorable effects on the Indian population were largely ascribed to biochemical and behavioral changes related to the reformed dietary habits 
Table 1 Currently available recommendations for medical nutrition therapy for the management of diabetes mellitus

RSSDI ADA ICMR

Carbohydrates

Recommended intake: $45-65 \%$ of total No specified recommended intake daily calories (minimum intake: $130 \mathrm{~g} /$ day)

High fiber diet: increased intake of soluble and insoluble fibers

Preferred sources: pulses, legumes, coarse grains, sprouted grams, unprocessed vegetables and fruits

Substitution of polished white rice with millets and brown rice

\section{Proteins}

Recommended intake: $10-15 \%$ of total daily calories

Preferred sources: not mentioned

Fats

Recommended calorie intake: no specified ideal intake

Restricted intake of saturated fats: $<10 \%$ of total daily calories

Minimal intake of trans fats
Recommended calorie intake: no specified ideal intake

Restricted intake of saturated fats: $<10 \%$ total daily calories

Minimal intake of trans fats
Recommended intake: $55-60 \%$ of total daily calories

High-fiber and low-glycemic index diet Intake of fiber-rich foods
Preferred sources: fruits, vegetables, whole, grains, legumes and dairy products (milk and yoghurt)

Typically $15-20 \%$ of total energy in individuals without diabetic kidney disease

Recommended daily allowance in individuals with T2DM and compromised renal function: of $0.8 \mathrm{~g} /$ $\mathrm{kg}$ body weight/day

Preferred sources: not mentioned
Preferred sources: cereals, mixed coarse grains, whole grains (e.g., ragi, oats, barley, jowar), whole pulses, whole fruits, salads and soybeans, leafy vegetables, fenugreek seeds

Restricted intake of all-purpose flour (maida)-based products

Recommended intake: $10-15 \%$ of total daily calories

Preferred sources: vegetable sources, low-fat milk and milk products, fish and lean meat

Recommended calorie intake: $20-25 \%$ total daily calories

Restricted intake of saturated fats: $<7 \%$ total daily calories

Minimal intake of trans fats (hydrogenated vegetable fats)

Restricted intake of dietary cholesterol: Restricted intake of dietary cholesterol: Restricted intake of dietary cholesterol: $<300 \mathrm{mg} /$ day $<300 \mathrm{mg} /$ day $<300 \mathrm{mg} /$ day 
Table 1 continued

\begin{tabular}{|c|c|c|}
\hline RSSDI & ADA & ICMR \\
\hline $\begin{array}{l}\text { Preferred sources of MUFA/PUFA: } \\
\text { moderate intake of fish/seafood, } \\
\text { chicken without skin and red meat }{ }^{\mathrm{a}} \\
\text { as a source of PUFA }\end{array}$ & $\begin{array}{l}\text { Preferred sources of MUFA/PUFA: } \\
\text { fatty fish, nuts and seeds }\end{array}$ & $\begin{array}{l}\text { Preferred sources of MUFA/PUFA: } \\
\text { groundnut, sesame, cotton seed, rice } \\
\text { bran or safflower along with soybean, } \\
\text { mustard, canola, etc., as preferred }\end{array}$ \\
\hline Not recommended: sunflower oil & & $\begin{array}{l}\text { choices for edible oils containing } \\
\text { MUFA and PUFA }\end{array}$ \\
\hline
\end{tabular}

Sugars and sweeteners

Reduced intake of refined sugars

Moderate intake of non-nutritive artificial sweeteners

Avoid consumption of HFCS
Reduced intake of HFCS and sucrose

Substitute nutritive sweeteners with non-nutritive sweetener

Natural fructose/free fructose from fruits (3-4\% of energy intake and not $>12$ ) is permissible
Avoidance of sugar, honey, jaggery

Restricted use of artificial sweeteners and avoidance in pregnant/lactating women with diabetes

Avoidance of very sweet fruits and fruit juices

Not recommended
Restricted intake of dietary salt:

$$
\leq 6 \mathrm{~g} / \text { day }
$$

Moderate of alcohol consumption

Cessation of any form of tobacco use

Cessation of tobacco use

Restricted sodium intake:

Moderate alcohol consumption

a Particularly in patients with established cardiovascular disease

b Insufficient evidence available

c Further restriction in patients with diabetes and hypertension

ADA American Diabetes Association, HFCS high-fructose corn syrup, ICMR Indian Council of Medical Research, MUFA mono-unsaturated fatty acids, PUFA poly-unsaturated fatty acids, RSSDI Research Society for the Study of Diabetes in India, $T 2 D M$ type 2 diabetes mellitus

and independent of reductions in BMI as observed in the global studies.

Implementation of community empowerment health programs and dietary counseling in MNT-based model meals in several rural and urban populations from the south and north of India have shown the benefits of dietary changes in the prevention of diabetes [46-48]. In a large randomized controlled translational study from India, a stepwise diabetes prevention program lowered the 3-year risk of diabetes by 32\% (95\% CI 7-50) in obese participants with any form of prediabetes [49]. Expert recommendations included addition of metformin to culturally adjusted lifestyle lessons. Participants were counseled to improve their diet habits, track and control their weekly dietary intake and follow a low-fat diet rich in complex carbohydrates and fresh fruits and vegetables. Other randomized controlled studies have documented the benefits 
Table 2 Dietary strategies employed in landmark studies

\begin{tabular}{|c|c|c|c|c|}
\hline Study & Population & Treatment goal & $\begin{array}{l}\text { Treatment strategy } \\
\text { (interventional } \\
\text { group) }\end{array}$ & Findings \\
\hline $\begin{array}{l}\text { Finnish } \\
\quad \text { Diabetes } \\
\text { Prevention } \\
\text { Study } \\
{[41,42]}\end{array}$ & $\begin{array}{l}\text { IGT (2-h plasma } \\
\text { glucose } \\
7.8 \pm 11.0 \mathrm{mmol} / \\
\text { 1) } \\
\text { BMI }>25 \mathrm{~kg} / \mathrm{m}^{2} \\
\text { (overweight) }\end{array}$ & $\begin{array}{l}\text { To delay development of } \\
\text { type } 2 \text { diabetes in high- } \\
\text { risk individuals with IGT, } \\
\text { at least as long as the } \\
\text { intervention prevents } \\
5 \% \text { weight loss or BMI } \\
<25 \mathrm{~kg} / \mathrm{m}^{2} \text { or weight } \\
\text { loss of } 5-10 \mathrm{~kg} \text { depending } \\
\text { on the degree of obesity }\end{array}$ & $\begin{array}{l}\text { Dietary strategy: } \\
\text { Carbohydrates: } 50 \% \\
\text { of daily calories } \\
\text { Saturated fats: } 10 \% \text { of } \\
\text { daily calories } \\
\text { Mono and } \\
\text { polyunsaturated fats: } \\
20 \% \text { of daily calories } \\
\text { Cholesterol: } \\
<300 \mathrm{mg} / \text { day } \\
\text { Dietary fiber to } 15 \mathrm{~g} \\
\text { per } 1000 \mathrm{kcal} \text { or } \\
\text { more } \\
\text { Physical activity: } \\
30 \text { min/day or more }\end{array}$ & $\begin{array}{l}\text { Compared with control } \\
\text { group 3\% reduction in } \\
\text { the relative risk of } \\
\text { developing type } 2 \\
\text { diabetes was observed in } \\
\text { the intervention group }\end{array}$ \\
\hline $\begin{array}{l}\text { Diabetes } \\
\text { Prevention } \\
\text { Programme } \\
\text { [39] }\end{array}$ & $\begin{array}{l}\text { IGT (2-h plasma } \\
\text { glucose } \\
\text { 140-199 mg/dl } \\
\text { based on } 75-\mathrm{g} \\
\text { OGTT) } \\
\text { BMI }>24 \mathrm{~kg} / \mathrm{m}^{2} \\
\left(>22 \mathrm{~kg} / \mathrm{m}^{2}\right. \\
\text { among Asian } \\
\text { Americans) }\end{array}$ & $\begin{array}{l}\text { To delay development of } \\
\text { type } 2 \text { diabetes in high- } \\
\text { risk individuals with IGT } \\
7 \% \text { weight loss in first } \\
6 \text { months and } \\
\text { maintenance of weight } \\
\text { loss throughout the study }\end{array}$ & $\begin{array}{l}\text { Dietary strategy: } \\
\text { Individual based } \\
\text { (individual model of } \\
\text { treatment) } \\
\text { Initial phase-to } \\
\text { reduce total fat } \\
\text { rather than calories, } \\
\text { overall healthy eating } \\
\text { Later phase-calorie } \\
\text { balance: restrict } \\
\text { calories and fat } \\
\text { To achieve } 1-2 \mathrm{lb} / \\
\text { week weight loss } \\
\text { Physical activity: } \\
150 \text { min/week of } \\
\text { moderate physical } \\
\text { activity (700 kcal/ } \\
\text { week expenditure) }\end{array}$ & $\begin{array}{l}\text { Lifetime intervention } \\
\text { resulted in } 58 \% \text { reduction } \\
\text { in the incidence rate of } \\
\text { diabetes }\end{array}$ \\
\hline
\end{tabular}


Table 2 continued

\begin{tabular}{|c|c|c|c|c|}
\hline Study & Population & Treatment goal & $\begin{array}{l}\text { Treatment strategy } \\
\text { (interventional } \\
\text { group) }\end{array}$ & Findings \\
\hline $\begin{array}{l}\text { Look AHead } \\
\text { Study } \\
{[55,151]}\end{array}$ & $\begin{array}{l}\text { Confirmed type } 2 \\
\text { diabetes } \\
\text { BMI } \geq 25 \mathrm{~kg} / \mathrm{m}^{2} \\
\left(\geq 27 \mathrm{~kg} / \mathrm{m}^{2} \text { in }\right. \\
\text { patients taking } \\
\text { insulin) }\end{array}$ & $\begin{array}{l}\text { To achieve and maintain } \\
\text { (long term: up to } \\
11.5 \text { years) weight loss in } \\
\text { patients with type } 2 \\
\text { diabetes to reduce } \\
\text { cardiovascular morbidity } \\
\text { and mortality } \\
7 \% \text { weight loss in first year }\end{array}$ & $\begin{array}{l}\text { Dietary strategy: } \\
\text { Similar to Finnish } \\
\text { Diabetes Prevention } \\
\text { study } \\
\text { Initial phase- } \\
\text { portion control diet } \\
\text { containing food with } \\
\text { fixed calorie and } \\
\text { macronutrient } \\
\text { content } \\
\text { Later phase-diet } \\
\text { modifications } \\
\text { depending upon } \\
\text { individual weights } \\
\text { Physical activity: } \\
175 \text { min/week } \\
\text { moderate physical } \\
\text { activity }\end{array}$ & $\begin{array}{l}\text { At } 1 \text { year, lifetime } \\
\text { intervention group lost } \\
8.6 \% \text { of their initial body } \\
\text { weight while the DSE } \\
\text { group lost } 0.7 \% \text {. At study } \\
\text { end, lifetime intervention } \\
\text { group had a } 6 \% \text { weight } \\
\text { loss while DSE had } 3.5 \% \text {. } \\
\text { With regard to fitness, } \\
\text { lifetime intervention had } \\
\text { greater improvement in } \\
\text { heart rate recovery after } \\
\text { graded exercise testing } \\
\text { compared with DSE }\end{array}$ \\
\hline
\end{tabular}

$B M I$ body mass index, DSE diabetes support and education, $I G T$ impaired glucose tolerance, $O G T T$ oral glucose tolerance test

of dietary approaches such as high-protein meal replacement and substitution of polished white rice with whole grain brown rice for diabetes prevention [50, 51]. There is no clear evidence supporting the use of micronutrients for primary prevention of chronic diseases such as diabetes [30, 31, 52-54]. However, supplementation with micronutrients (chromium, alpha lipoic acid, zinc, magnesium, etc.) having potential health benefits can be considered for adjuvant nutritional care [54]. Thus, carefully crafted MNT has the potential to reduce the onset of T2DM in Indians at risk for T2DM, especially overweight individuals and women with gestational diabetes [49].

\section{Box.1: Evidence-based dietary recomm endations for the prevention of T2DM}

- Reduce intake of refined carbohydrates and sugars

- Restrict intake of nonnutritive sweeteners

- Reduce intake of total fats $(<20 \mathrm{~g} /$ day $)$ and saturated fats

- Increase consumption of high-fiber foods: legumes, whole grains, fruits and vegetables, millets

- Substitute polished white rice with whole grain brown rice 


\section{MEDICAL NUTRITION THERAPY FOR THE MANAGEMENT OF T2DM}

Based on the World Health Organization (WHO) criteria and RSSDI diagnosis guideline, an FPG of $\geq 126 \mathrm{mg} / \mathrm{dl}$ or random blood glucose of $\geq 200 \mathrm{mg} / \mathrm{dl}$ (or HbA1c of $\geq 6.5 \%$ ) and the presence of conventional signs and symptoms are considered to indicate diabetes $[29,30]$. The Look Ahead study was designed to evaluate the effects of an intensive regimented lifestyle intervention program in controlling glycemia and preventing cardiovascular complications (Table 2) [55]. The diet goal was to restrict fat to less than $30 \%$ of calorie intake and reduce intake of high-GI carbohydrates such as sugar, flavored beverages and high-calorie snacks. At 11 years, participants reported an average of 5\%weight loss and substantial improvements in HbA1c levels, systolic and diastolic blood pressure, high-density lipoprotein (HDL) cholesterol, triglycerides, and overall fitness and well-being [55]. A 12-month prospective randomized study from India reported the success of a dietician-led evidence-based MNT implementation of a high-carbohydrate, high-fiber (HCHF) diet [57-60]. Consumption of an HCHF diet was associated with long-term adherence and higher acceptability compared with carbohydrate-restricted diets that dramatically altered the standard Indian diet (cereal-based, $70-80 \%$ calories from carbohydrates) $[57,58]$. Recent studies further provide clinical and scientific support of the usefulness of a long-term HCHF diet in promoting weight loss, improving glycemic control and lowering cardiovascular risk [61-64]. Population-based studies from India have documented the association between overconsumption of refined grains that lack dietary fibers and vital micronutrients and saturated fats with insulin resistance and poor glycemic control, whereas intake of fiber-rich foods, fruits and vegetables has shown a negative correlation $[8,65,66]$. A prospective study conducted in Indian participants with T2DM on oral hypoglycemic medications demonstrated the success of a structured diet plan comprising a modified traditional Indian to lower GI and glycemic load (GL) diet [67].

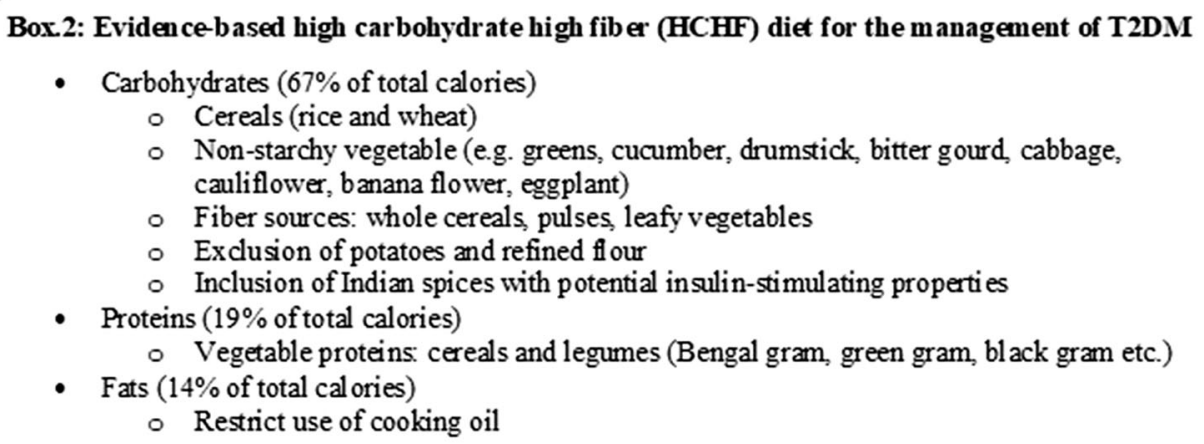

individualized for macronutrient intake and restricted intake of sugars. Participants with T2DM, randomized to MNT, achieved significant improvements in HbA1c in all lipid parameters, especially triglyceride levels [56].

Although there appears to be a universal tenet to restrict carbohydrates in T2DM diet plans, historic data from India support the
These modifications regulated the glycemic load (snacks 15.28-23 g; meals 12.75-20.75 g) of these diets, which could potentially dampen postprandial glucose elevations [67]. Similar approaches to improve the glycemic quality of staple Indian flatbreads (such as naan, rotis or chapattis) by fortifying the wheat flour with soluble viscous fibers and legume flour was 
associated with favorable postprandial glucose and insulin responses in patients with T2DM [68-70].

Multivitamin supplementation may be needed to address inadequacies or deficiencies in vitamins $\mathrm{A}, \mathrm{C}$ and $\mathrm{E}$, thiamine, pyridoxine, B12 and biotin, which are common in patients with diabetes. Particularly patients on metformin therapy need B12 and folic acid supplements, as prolonged use of metformin decreases the absorption of these vitamins [71, 72]. Evidence from clinical studies have shown the benefits of chromium, vitamin D3, magnesium and zinc supplementation in improving the lipid profile, insulin sensitivity, glucose metabolism and overall metabolic control in patients with T2DM [73-76]. However, there are no definitive recommendations for the dose and duration of these therapies, and there are limited safety and efficacy data to support routine use of vitamins and other micronutrients in the management of T2DM [31, 52]. People with diabetes should be educated about the importance of consuming nutrient-dense foods such as fruits and vegetables and a well-balanced diet to ensure adequate micronutrient intake for the maintenance of a healthy lifestyle [28]. expand the focus of care beyond glycemic control. A positive correlation between insufficient nutritional knowledge and diabetic foot [odds ratio 3.86 (95\% CI 0.99-14.98), $p=0.051]$ and coronary artery disease [odds ratio 2.23 (95\% CI 1.13-4.40), $p=0.021$ ] was observed in women with diabetes [77]. Results from landmark studies such as the Diabetes Control and Complications Trial (DCCT) and the UK Prospective Diabetes Study (UKPDS) have provided compelling evidence for the role of MNT in preventing micro- and macrovascular complications of diabetes [21, 78]. A significant influence of nutritional status on limb-preservation outcomes has been observed in patients with limb-threatening diabetic foot ulcers [79]. A 20-week dietary intervention comprising a plant-based diet (vegetables, fruits, grains and legumes) favoring intake of low-GI carbohydrates and limited fat intake (20-30 g/day) along with vitamin B12 supplementation was found to dampen or halt sudomotor nerve function decline in patients with T2DM and painful diabetic neuropathy [80]. Studies have documented the increased risk of malaria in individuals with subclinical or overt T2DM, and the high frequency of both diseases in India increases the clinical challenges [81, 82].

Box.3: Evidence-based dietary recommendations for the management of T2DM

- Reduce intake of refined foods

- Reduce intake of total fats (20 to $30 \mathrm{~g} /$ day) and saturated fats

- Increase intake of fiber-rich foods: legumes, sprouts, whole grains, fruits and vegetables

- Increase intake of protein (20\%-25\%) and dietary fiber (44 to $50 \mathrm{~g}$ )

- Restrict intake of sucrose and nonnutritive sweeteners

- Adopt regulated daily meal plans comprising low GI carbohydrates (snacks: 15.28 to $23 \mathrm{~g}$; meal s: 12.75 to $20.75 \mathrm{~g}$ )

- Fortify wheat flour with soluble viscous fibers and legume flour (e.g. guar gum, chickpea flour, barley)

\section{MEDICAL NUTRITION THERAPY FOR COMPLICATIONS OF T2DM}

As the majority of morbidities and mortalities due to T2DM are attributed to micro- and macrovascular complications, it is important to
Clinicians and dieticians should be wary of the false $\mathrm{HbA} 1 \mathrm{c}$ because of the abnormal red blood cell turnover in malaria, and adjustments in MNT should be made cautiously [83]. Conditions such as hemoglobinopathy, especially $\mathrm{HbE}$ disease (prevalent in northeast India), or iron deficiency anemia could falsely alter HbA1c results $[84,85]$. 
Hence, dieticians should be cautious about recommending an MNT diet for these patients with diabetes. Calorie restrictions in individuals with T2DM should be monitored to avoid malnourishment and deficiencies in vitamin A, B complex, zinc, iron and folate that may increase the risk of or complicate malarial infections by affecting immunity and pathophysiology [86]. Coexistence of hyperuricemia in prediabetes or T2DM also demands alterations in diet plans and exclusion of purine-rich foods such as fructose-based beverages, red meat, animal fat, alcohol, etc. [87]. High incidences of celiac disease, especially in northern India, and co-occurrence of celiac disease with T2DM predispose patients to severe comorbidities $[88,89]$. Thus, dietary counseling in these patients should advocate intake of gluten-free foods and inclusion of pre- and probiotics, which may be useful to restore the natural microbiota balance and alleviate symptoms [90].

The following sections discuss evidence for MNT recommendations for the management of common diabetes-associated complications.

\section{Cardiovascular Complications}

The RSSDI recommends consumption of a fiber-rich cardio-protective diet in patients with T2DM and established cardiovascular disorder [30]. Lower incidence of micro-albuminuria (5.3\% vs. $8.8 \%, p<0.01)$, chronic heart failure $(2.7 \%$ vs. $4.6 \%, p<0.01)$ and intermittent claudication (3.3\% vs. $5.3 \%, p<0.01)$ were reported in patients with T2DM receiving MNT and antidiabetic medications compared with the patients receiving antidiabetic medications alone [91].

The large multinational PURE study concluded that high carbohydrate diets $(\geq 60 \%$ of total calories) correlated with a higher risk of mortality and high intake of total fats (saturated and MUFA fatty acids from beef, lamb and dairy) irrespective of the type of fat correlated with lower mortality due to cardiovascular disease [92]. However, substantial evidence exists suggesting the importance of the type of fat on cardiovascular outcomes and concerns about increasing intake of total and saturated fats [93]. Omega 6 and omega 3 polyunsaturated fats especially from plant oils have been inversely related to cardiovascular diseases and T2DM [94, 95]. The PREDIMED study demonstrated a lower incidence of cardiovascular disease in a high-risk population by replacing saturated fats with PUFA using a classic Mediterranean diet (fish, monounsaturated fats from olive oil, fruits, vegetables, whole grains, legumes/nuts and moderate alcohol consumption) [96]. In a post hoc analysis of the PREDIMED study, a lower risk of diabetic retinopathy was observed in the participants following a Mediterranean diet supplemented with extra-virgin olive oil [HR 0.56 (95\% CI 0.32-0.97)] and mixed nuts [HR 0.63 (95\% CI 0.35-1.11)] compared with those on the control diet [97].

Although the PURE study did not report associations between the type of carbohydrate and increased cardiovascular mortality risk, increased intake of dietary fibers has been associated with favorable cardiovascular outcomes in patients with T2DM [98, 99]. Consumption of high fiber diets in patients with T2DM did not precipitate hypertriglyceridemia and corrected dyslipidemia $[57,58,64]$. Thus, given the prevalence of undernutrition and high consumption of a carbohydrate-based vegetarian diet, the influence of both types of carbohydrates and fats are more relevant in Indian patients with T2DM.

Overall, based on an assessment of the prevalence of cardiovascular comorbidities and risk factors in urban Indian populations, a diet rich in complex carbohydrates $(65 \%$ of total calories), high daily intake of $400 \mathrm{~g}$ fruits, vegetables and legumes, cereals supplemented with $25 \mathrm{~g}$ soybeans or mustard or canola oils (rich in n-3 fatty acids) in place of saturated fat was described to be protective against diabetes and associated vascular complications [100]. Another study documented significant improvements in the glycemic control, waist circumference, lipid profile, HbA1c and high-sensitivity C-reactive protein level following intervention with an almond-based diet (carbohydrates 55\%; protein 17\%; and fat 28\%) in participants with T2DM on stable metformin treatment [101]. Daily consumption of $3 \mathrm{~g}$ of soluble fiber from $70 \mathrm{~g}$ of oats in the form of 
porridge or upma (a thicker form of porridge with added seasoning and vegetables) was found to lower serum total cholesterol and LDL cholesterol in hypercholesterolemic Asian Indians, suggesting the role of dietary fibers in improving dyslipidemia [102]. This evidence supports an integral role of local culinaryoriented MNT in improving cardiovascular health in individuals with diabetes. retard the progression of nephropathy and delay the onset of end-stage renal disease.

The mean protein intake among Indian patients with T2DM usually does not exceed the recommended dietary protein intake $(0.8 \mathrm{~g} / \mathrm{kg}$ body weight/day) in patients with compromised renal function. It is observed that the mean protein content of Indian diets and average protein intake in both vegetarians and non-vegetarians are generally low (higher in non-vegetarian versus vegetarian diets)

Box.4: Evidencebased dietary recomm endations for the management of T2DM and cardiovascular comorbidities

- Reduce intake of saturated fats and trans fots

- Increase intake of fiber-rich foods: leafy vegetables, coarse grains, sprouted grams etc.

- Avoid alcohol, refined carbohydrates, sugar and fried foods

- Increase consumption of fruits and vegetables

- Increase consumption of foods rich in omega -3 and 6 fatty acids

\section{Renal Insufficiency}

Dietary recommendations by the RSSDI for patients with diabetes and chronic kidney disease (CKD) with proteinuria suggest a restriction of the daily protein consumption $(<1 \mathrm{~g} / \mathrm{kg})$. Several studies have reported the efficacy of reduced protein and phosphorous intake in patients with compromised renal function [103-106]. Based on the available evidence, a protein intake of $0.6-0.8 \mathrm{~g} / \mathrm{kg}$ of body weight per day comprising $25-50 \%$ high biologic value protein is recommended in persons with impaired renal function $[107,108]$.

A meta-analysis of studies evaluating the effects of low protein intake showed that dietary protein restriction is favorable in both diabetic and non-diabetic renal insufficiency [108]. Reduced protein intake lowered the risk of decline in the glomerular filtration rate and creatinine clearance (or an increase in the urinary albumin excretion rate). These effects were independent of alterations in blood pressure or glycemic control. Dietary protein restrictions therefore have protective effects, compared with the Western population, from which the majority of the recommended data is accrued [109]. The prevalence of microalbuminuria and proteinuria did not differ significantly between Indian T2DM vegetarian and non-vegetarian patients [109]. Thus, protein restrictions may not be necessary in Indian vegetarians with T2DM, and moderate restrictions of animal protein may be beneficial in non-vegetarians. Intake of vegetable proteins is preferred to avoid phosphate, sodium and potassium imbalances. Increased consumption of green leafy vegetables and fruits has been found to be beneficial in slowing down the progression of renal damage [107, 110].

Carbohydrates are recommended as the predominant source of energy ( 45-60\%). Intake of fiber-rich foods having low GI and restricted intake of sugars and refined carbohydrates are recommended [111, 112]. However, the potassium and phosphorous content in these foods should be taken into account, especially in advanced diabetic kidney disease [107]. Restricted sodium intake $[<1.5-2.3 \mathrm{~g}$ /day (5 $\mathrm{g}$ of sodium chloride)] may be recommended on a case-to-case basis; risk of 
impaired glucose metabolism and compromised insulin sensitivity due to excessively low sodium levels should be taken into account [107, 111]. Comorbid dyslipidemia in patients with renal insufficiency is common, and therefore reduced intake of saturated fats $(<7 \%$ of total daily calories) and trans fats is considered beneficial $[16,31]$. Dietary intake of omega-3 and 6 PUFAs and MUFAs has been positively associated with improvements in inflammatory responses and endothelial dysfunction in diabetic kidney disease [113]. Overall, individual diet plans and regular assessment of nutritional status to adjust for calorie losses and identify any harmful metabolic effects are recommended in patients with T2DM with renal insufficiency. encouraging results in young and adult patients with obesity [46, 114]. Studies from various parts of India have shown the clinical benefits of dietary intervention or reformed dietary habits in preventing obesity and T2DM. The dietary interventions achieved significant improvements in the anthropometric [waist circumference $(p=0.02)$, sagittal abdominal diameter $\quad(p<0.001)$, waist-to-hip ratio $(p=0.02)]$ and biochemical profiles [FPG $(p=0.05)][46,116]$.

The RSSDI recommends moderate calorie restriction to achieve $5-10 \%$ reduction in body weight, moderate exercise and changes in dietary composition in obese $\left(\mathrm{BMI}>25 \mathrm{~kg} / \mathrm{m}^{2}\right)$ patients with diabetes [30]. Low-fat, lowcarbohydrate or high-protein diets are common

Box.5: Evidence-based dietary recommendations for the management of T2DM and renal insufficiency

- Regulate protein intake: 0.6 to $0.8 \mathrm{~g} / \mathrm{kg}$ of body weight /day

- Preferred source of protein: vegetable protein

- Regulate phosphorous intake: $500-1000 \mathrm{mg}$ per/day

- Regulate intake of fruits and vegetables containing potassium and phosphorous

- Restrict sodium intake: $<1.5-2.3 \mathrm{~g} /$ day

- Increase intake of fiber-rich foods

\section{Diabetes and Obesity}

The surging prevalence of obesity is a leading cause of the morbidity and mortality associated with T2DM in India and other South Asian countries. Higher body fat, truncal adiposity, intra-abdominal visceral fat and ectopic fat deposition in South Asians predispose to the development of metabolic comorbidities [114]. Furthermore, South Asians have been shown to have an inherent low threshold to high-calorie diets compared with the Caucasian population and an innate inability to metabolically adapt to the high glucose rates of diabetes [115]. Early lifestyle management and appropriate dietary intervention are therefore absolutely necessary [114].

Increasing awareness of obesity-related cardiometabolic risks, management strategies and dietary education in particular has shown dietary approaches that can be individualized for achieving weight loss in patients with obesity and poor glycemic control [117-119]. These approaches have been correlated with favorable reductions in body weight, waist circumference and improvements in glycemic profile, insulin sensitivity and lipid profile [117-119]. In obese patients with T2DM (median HbA1c $=9 \%$ ) from India, a 12-week, low-calorie, all-day meal plan comprising 60\% carbohydrates, $30 \%$ proteins (major source: whey protein) and $10 \%$ fat demonstrated efficacy in lowering the HbA1c $(<6.5 \%)$ [120]. Improvements were also reported in indices of insulin resistance, beta cell secretory capacity, and insulin sensitivity and reduction in serum levels of liver transaminases in responders and liver fat depots [120]. These results underscore the advantage of a diet balanced in carbohydrates and proteins. Such diet plans may have better 
acceptability among Indians [57]. Healthy modifications in culinary practice such as avoiding reheating of oils, substituting frying with steaming, and reducing inclusion of refined carbohydrates and processed foods are suggested to have favorable impact on obesity, T2DM and associated metabolic abnormalities [121]. Although there are limited data from dietary intervention studies from India, the preferential intake of high fiber carbohydrates, MUFA and omega 3 PUFAs and increasing consumption of proteins could help weight loss and improve the glycemic and cardiometabolic status in individuals with T2DM [122].
Research supports the benefits of healthful dietary choices in lowering the incidence of IGT and GDM in pregnancy. Implementation of a personalized, hypocaloric, low-GI, lowsaturated fat diet and inclusion of leafy green vegetables, fruit and milk have been associated with lower GDM occurence [129-131]. Indian guidelines suggest that women with GDM must receive nutritional counseling. The meal pattern should provide adequate calories and nutrients to meet the metabolic needs of pregnancy while ensuring postprandial normoglycemia. In clinical practice, restriction of the carbohydrate intake to $30-40 \%$ of the total calories can reduce the insulin

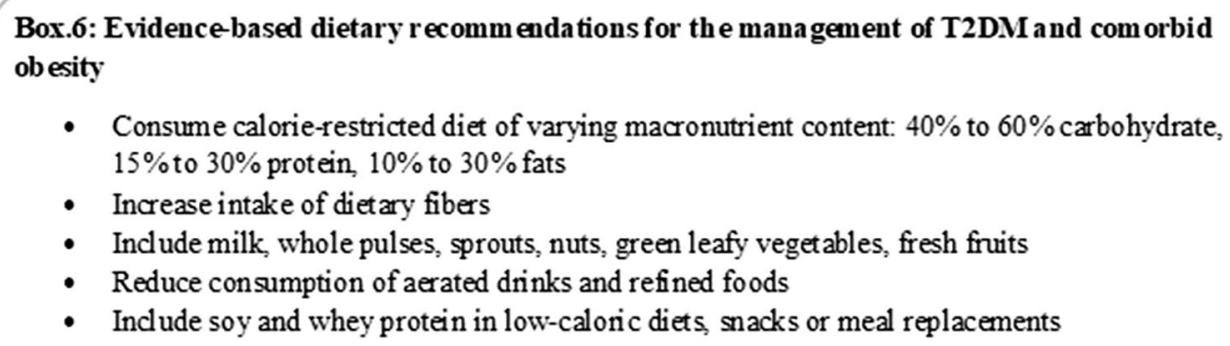

\section{MEDICAL NUTRITION THERAPY FOR THE MANAGEMENT OF GESTATIONAL DIABETES MELLITUS}

Gestational diabetes mellitus (GDM) is defined as glycemic dysregulation due to progressive changes in carbohydrate metabolism with onset or first recognition during pregnancy and has been identified as a critical risk factor for developing overt diabetes in the mother and child [123, 124]. The prevalence of GDM in India has risen exponentially, parallel to the increasing prevalence of diabetes; the prevalence of GDM is reported to be $16.2 \%$ in urban and $9.9 \%$ in rural areas of India [125]. MNT has been identified as the fundamental approach in the prevention and management of GDM. This therapy should ideally be developed, implemented and monitored by an RD or nutritionist [126-128]. requirement by half [132]. As a part of MNT, the Indian guideline recommends the distribution of calorie consumption and consuming portions with a 2-h gap in between to avoid excess weight gain and maintain optimal glycemic control [133]. Reduced intake of high-GI foods, substitution of fruit juices with whole pieces of fruit and preference for high-fiber foods-whole grains, whole fruits and vegetables, beans and legumes, and oats-help achieve optimum glycemic control in GDM [134-136]. Diet plans comprising three meals and there snacks at regular intervals are recommended to allow even distribution of carbohydrates throughout the day, control postprandial glucose excursions and manage the gestational deficiency in first phase insulin secretion [137-139]. Splitting the breakfast meal into two portions and consuming each portion with a 2-h gap are recommended to distribute the carbohydrate load and attenuate glycemic spikes [138, 139]. 
Box 7. Suggested calorie distribution in women with GDM

- Breakfast: $10-20 \%$ of total calories, divided into two meals consumed 2 hours apart

- Lunch $-20-30 \%$ of total cal ories

- Dinner $-30-40 \%$ of total calories

- Snacks - Up to $30 \%$ of total calories. Snacking is based on caloric needs and support for hypoglycemia as well as consideration of pre-pregnancy BMI, as overweight and obese women may not need to snack. Bedtime snacks are often needed to minimize noctumal hypoglycaemia

\begin{tabular}{ll|ll}
\hline \multicolumn{4}{c}{ Average daily allowance in women with GDM } \\
\hline \multicolumn{3}{c}{ Total cal ories 2,200 cal } \\
\hline Protein & $50 \mathrm{~g}$ & Vitamin C & $6 \mathrm{mg}$ \\
Vitamin B1 & $61.6 \mathrm{mg}$ & Folic acid & $0.4 \mathrm{mg}$ (up to 4 to $5 \mathrm{mg}$ ) \\
Calcium & $800 \mathrm{mg}$ & Magnesium & $280 \mathrm{mg}$ \\
Iron & $15 \mathrm{mg}$ & Zinc & $12 \mathrm{mg}$ \\
\hline
\end{tabular}

On average, the recommended weight gain during a single pregnancy is $300-400 \mathrm{~g} /$ week and total weight gain of up to $5-18 \mathrm{~kg}$ by term depending on the pre gravid BMI (lower gains in overweight women) [140-142]. Thus, structured dietary plans should allow sufficient calories for the mother and the developing fetus while avoiding weight gain and prandial hyperglycemia. The calorie requirement should be individualized based on multiple factors such as age, activity, pre-pregnancy weight, stage of pregnancy and regular blood glucose measurements $[14,143]$. No incremental calorie intake is recommended during the first trimester, and approximately 300-340 kcal/day above the basal requirement (only in the second and third trimester) is regarded as adequate. Although these calorie requirements are not standardized and need to be individualized, a daily calorie intake of 1500-2800 calories, not exceeding $1800 \mathrm{kcal} /$ day in obese women with GDM, has been correlated with successful pregnancy outcomes [14, 132]. Monitoring of body weight and blood glucose is recommended at each visit to evaluate and modify MNT. As GDM increases the risk of maternal T2DM, annual postpartum follow-ups are recommended to allow adjustments to MNT [128].

Box 8. Prepregnancy body mass index-adjustm ent calorie requir em ents during pregnancy

- Underweight $\left(<18.5 \mathrm{~kg} / \mathrm{m}^{2}\right): 30 \mathrm{kcal} / \mathrm{kg}$ in the first trimester, 36 to $40 \mathrm{kcal} / \mathrm{kg}$ in the second and third trimesters

- Normal weight $\left(18.5-24.9 \mathrm{~kg} / \mathrm{m}^{2}\right): 30 \mathrm{kcal} / \mathrm{kg}$ in the first trimester, $36 \mathrm{kcal} / \mathrm{kg}$ in the second trimester, and 36 to $38 \mathrm{kcal} / \mathrm{kg}$ in the third trimester

- Overweight (25-29.9 $\left.\mathrm{kg} / \mathrm{m}^{2}\right): 24 \mathrm{kcal} / \mathrm{kg}(22-25)$ throughout pregnancy

- Morbidly obese $\left(>30 \mathrm{~kg} / \mathrm{m}^{2}\right): 12-14 \mathrm{Kcal} / \mathrm{kg}$ (minimum $1,800 \mathrm{cal} /$ day to prevent ketosis) 


\section{IMPORTANCE OF MEDICAL NUTRITION THERAPY IN SPECIAL POPULATIONS}

\section{Diabetes Mellitus and Tuberculosis}

The syndemic association between diabetes and tuberculosis (TB) is a growing concern in India, and patients with the double burden represent an important population who need appropriate nutritional care [144]. A compromised innate and adaptive immune response in diabetes and an endocrine-linked metabolic response to stress suggest a two-way association between diabetes and tuberculosis. An expanding evidence base reflects the increasing prevalence of the double burden with rates ranging from $10 \%$ to $44 \%$ in India. The RSSDI advocates adoption of lifestyle modifications including dietary intervention as an essential part of the management strategy recommended for the double burden [144]. It is recommended that proteins should be the major source of energy in patients with coexisting diabetes and TB without renal or hepatic insufficiency. In patients experiencing extreme weight loss associated with $\mathrm{TB}$ (weight loss of $>10 \%$ within 3-6 months), inclusion of 500 calories essentially from protein sources is recommended [144]. Intake of dietary fibers and moderate amounts of fats supplemented with appropriate intake of vitamins (especially vitamin D, B6 and B12) and minerals are considered beneficial for patients with concurrent diabetes and TB [145]. Considering the lower protein intake among Indians and increased micronutrient requirements, meal replacements or between-meal protein-rich snacks may be a useful approach to adequate supplementation in patients with T2DM and coexisting TB.

\section{CLINICAL EXPERIENCE AND IMPLICATIONS OF MNT IN T2DM}

Evidence from the global and Indian population with T2DM suggests that MNT is as advantageous as pharmacologic intervention and should be implemented with equal importance and rigor. MNT is a life-enhancing process, and its implementation demands alterations in established eating patterns and habits. MNT requires adherence to a healthy diet on a longterm basis to achieve short- and long-term goals of improving the patient's metabolic status. MNT is not limited to calorie restriction and portion control. It involves designing signature meal plans that incorporate the individual's preferred foods and eating patterns and match the nutritional intake with the metabolic pathophysiology (prediabetes, early or late T2DM). Thus, nutritional care is a complex process. For the best results, MNT should support and synergize with antidiabetic medication therapy. Continuous reliance on antidiabetic medication therapy alone, or MNT alone, may be inadequate to achieve glycemic control. Hence, both therapies must be evaluated and modified as per requirements at every clinical visit. It is therefore recommended to establish a strong referral network between the clinician and RD or nutritionist. This will help improve the outcomes, overall well-being and quality of life in a cost-effective manner [38, 146]. We recommend that all physicians caring for diabetes patients empanel an RD and use the following steps for the implementation of MNT in clinical practice in India (Fig. 1).

\section{STEP 1: INITIAL NUTRITION WORKUP AND ASSESSMENT}

A diet history questionnaire (Table 3) helps record the diet history in individuals at risk or at diagnosis of T2DM. This initial workup should be conducted at first presentation and may involve a series of meetings with the diabetologist and RD. It should help understand the nutritional needs of the patient and at the same time provide a reasonable idea about the patient's habitual food intake, likes, dislikes and lifestyle. Through this assessment, the $\mathrm{RD}$ can also gauge the patient's ability and willingness to follow diet plans. Discussion about busy schedules or erratic lifestyles, family support, resource limitations, culinary practices, religious 
Table 3 Sample diet history questionnaire

\begin{tabular}{|c|c|c|c|c|c|c|c|c|}
\hline \multicolumn{9}{|c|}{ Diet history Questionnaire } \\
\hline \multicolumn{9}{|c|}{ Question 1: Quantities of the following food consumed by the family } \\
\hline 1. Cooking oil & Gingelly & Groundnut & Mustard & Rice bran & Sunflower & Ghee & Butter & \\
\hline \multicolumn{9}{|l|}{ Kgs/month } \\
\hline 2. Vegetables & Beans variety & \begin{tabular}{|l|}
$\begin{array}{l}\text { Gourds/ watery } \\
\text { vegetables }\end{array}$ \\
\end{tabular} & $\begin{array}{l}\text { English } \\
\text { vegetables }^{\mathrm{a}}\end{array}$ & $\begin{array}{l}\text { Traditional } \\
\text { vegetables }\end{array}$ & $\begin{array}{l}\text { Salad } \\
\text { vegetables }\end{array}$ & \begin{tabular}{|l|}
$\begin{array}{l}\text { Roots and } \\
\text { tubers }\end{array}$ \\
\end{tabular} & Milk & \\
\hline \multicolumn{9}{|l|}{ Kgs cooked per day } \\
\hline 3. Fruits & Citrus fruits & Plantain & Seasonal fruit & Papaya & Sweet Lime & Chikoo & Others & \\
\hline \multicolumn{9}{|l|}{ Quantity } \\
\hline \multicolumn{9}{|c|}{ Question 2: Food frequency questionnaire } \\
\hline $\begin{array}{l}\text { 1. Food stuff } \\
\text { cereals }\end{array}$ & Oats & Rava & Rice & Vermicelli & Wheat & & & \\
\hline \multicolumn{9}{|l|}{ Weekly and Monthly } \\
\hline 2. Vegetables & Brinjal & Cauliflower & $\begin{array}{l}\text { Bangalore } \\
\text { brinjal (Cho- } \\
\text { chomarrow) }\end{array}$ & Cucumber & Drumstick & Field beans & French beans & Gourd others \\
\hline \multicolumn{9}{|l|}{ Weekly and Monthly } \\
\hline & Bitter gourd & \begin{tabular}{|l|}
$\begin{array}{l}\text { Wild cabbage } \\
\text { (Knol-Khol) }\end{array}$ \\
\end{tabular} & Ladies finger & Peas, green & Plantain, green & Plantain stem & Tomato & \\
\hline 3. Flesh foods & Chicken & Sea food & Egg & Fish & Mutton & Liver & & \\
\hline \multicolumn{9}{|l|}{ Weekly and Monthly } \\
\hline 4. Nuts & Almonds & Walnuts & Cashew nut & Coconut & $\begin{array}{l}\text { Fresh } \\
\text { groundnut }\end{array}$ & & & \\
\hline \multicolumn{9}{|l|}{ Weekly and Monthly } \\
\hline 5. Pulses/ Legumes & \begin{tabular}{|l|} 
Bengal gram \\
dal
\end{tabular} & \begin{tabular}{|l|}
$\begin{array}{l}\text { Bengal gram } \\
\text { whole }\end{array}$ \\
\end{tabular} & Black gram dal & $\begin{array}{l}\text { Green gram } \\
\text { whole }\end{array}$ & $\begin{array}{l}\text { Peas, dry red } \\
\text { gram dal }\end{array}$ & Soya beans & & \\
\hline \multicolumn{9}{|l|}{ Weekly and Monthly } \\
\hline 6. Leafy vegetables & Amaranth & $\begin{array}{l}\text { Amaranthus } \\
\text { leaves (Arai } \\
\text { keerai or cholai } \\
\text { leaves) } \\
\end{array}$ & Cabbage & $\begin{array}{l}\text { Coriander } \\
\text { leaves }\end{array}$ & $\begin{array}{l}\text { Drumstick } \\
\text { leaves }\end{array}$ & Mint leaves & & \\
\hline \multicolumn{9}{|l|}{ Weekly and Monthly } \\
\hline 7. Roots and Tubers & Beet root & Carrot & Colocasia & Garlic & Onion & Potato & Radish & $\begin{array}{l}\text { Yam elephant// } \\
\text { Yam ordinary }\end{array}$ \\
\hline \multicolumn{9}{|l|}{ Weekly and Monthly } \\
\hline 8. Fruits & Apple & Banana & Grapes & Guava & Mango & Water melon & Orange & Papaya \\
\hline \multicolumn{9}{|l|}{ Weekly and Monthly } \\
\hline $\begin{array}{l}\text { 9. Milk and milk } \\
\text { products }\end{array}$ & Curd & Buttermilk & Ghee & Milk & & & & \\
\hline \multicolumn{9}{|l|}{ Weekly and monthly } \\
\hline 10. Sugars & Honey & Jaggery & Sugar & & & & & \\
\hline \multicolumn{9}{|l|}{ Weekly and Monthly } \\
\hline \multicolumn{9}{|c|}{ Question 3: Are you allergic to any food? If yes, list the food items } \\
\hline \\
\hline \multicolumn{9}{|c|}{ Question 4: Give a list of likes and dislikes in food items and preparations } \\
\hline $\begin{array}{l}\text { Likes } \\
1 . \\
2 . \\
3 .\end{array}$ & & & & $\begin{array}{l}\frac{\text { Dislikes }}{1 .} \\
2 . \\
3 .\end{array}$ & & & & \\
\hline
\end{tabular}


Table 3 continued

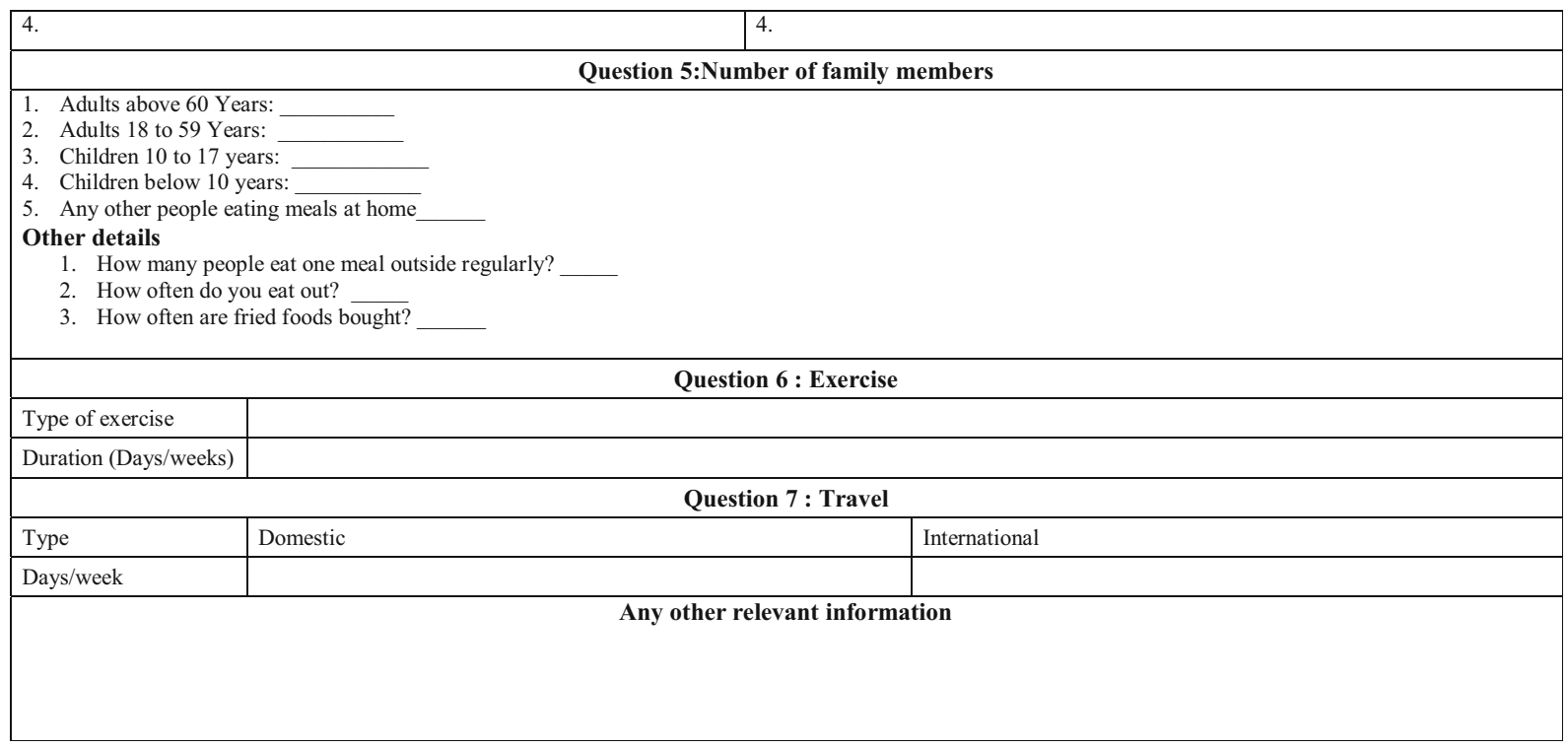

a English vegetables include cabbage, cauliflower, French beans, broccoli, lettuce, Brussel sprouts etc.

taboos and the presence of metabolic and non-metabolic conditions that may necessitate avoiding certain foods is part of the initial nutritional assessment.

\section{STEP 2: DIAGNOSIS OF NUTRITION NEEDS}

This step involves a careful assessment of the patient's clinical profile to identify potential risk factors (e.g., presence of infections, celiac diseases, comorbid conditions, etc.), the environmental and behavioral profile, and food intake to determine the nutritional quality. Physiologic classification of food items based on their carbohydrate quality is a reliable method of determining their postprandial glycemic effect [147]. A food with a high GI raises blood glucose more than a food with a medium to low GI. However, the GI does not take into account the amount of carbohydrate in a food item; hence, the GL is a better indicator of how a typical serving of carbohydrate-containing food will affect the blood glucose [147, 148]. A low GL is between 1 and 10; a moderate GL is 11-19; a high GL is $\geq 20$. Long-term consumption of a high GL diet has been identified as an independent determinant of T2DM, and inclusion of low GI foods has shown favorable glycemic effects [147-149]. Information on the GI of various food items can therefore be instrumental in developing meal plans for patients with T2DM. Given that Indian diets are predominantly carbohydrate-based, these assessments become more relevant (Table 4). At the end of this step, the RD will have a clear picture of the coexisting metabolic and non-metabolic conditions and quality of carbohydrates currently consumed, which will assist with calculations and adjustments while planning the nutritional intervention.

\section{STEP 3: INITIATING MEDICAL NUTRITION THERAPY}

This step includes developing meal plans with a focus on nutrient intake and providing nutritional education, counseling and coordination of care. As there are no gold standards or prototypical diets, signature diet plans need to be developed based on individual nutrition goals. Providing healthful food choices, 
Table 4 The average glycemic index of 27 common foods derived from multiple studies References: Atkinson et al. [153]

\begin{tabular}{|c|c|c|c|c|c|}
\hline $\begin{array}{l}\text { Uncooked } \\
\text { food }\end{array}$ & $\begin{array}{l}\text { Glycemic index } \\
(\text { glucose }=100)\end{array}$ & $\begin{array}{l}\text { Glycemic } \\
\text { load }^{\mathrm{a}}\end{array}$ & Cooked food (serving size, $\mathrm{g}$ ) & $\begin{array}{l}\text { Glycemic index } \\
(\text { glucose }=100)\end{array}$ & $\begin{array}{l}\text { Glycemic } \\
\text { load }^{\mathbf{b}}\end{array}$ \\
\hline Apple & $36 \pm 3$ & 5 & Bajra roti & 67 & - \\
\hline $\begin{array}{l}\text { Apricots, } \\
\text { dried }\end{array}$ & 32 & 10 & Maize chapatti & 64 & - \\
\hline Banana & $48 \pm 3$ & 11 & $\begin{array}{l}\text { Wheat chapatti served with bottle gourd and } \\
\text { tomato curry }(60 \mathrm{~g})\end{array}$ & $66 \pm 9$ & 21 \\
\hline $\begin{array}{l}\text { Cherries, } \\
\text { raw, sour }\end{array}$ & 22 & 3 & $\begin{array}{l}\text { Wheat chapatti served with green gram dal } \\
(200 \mathrm{~g})\end{array}$ & $81 \pm 4$ & 41 \\
\hline $\begin{array}{l}\text { Dates, } \\
\text { dried }^{c}\end{array}$ & $103 \pm 21$ & 42 & $\begin{array}{l}\text { Jowar roti (roasted bread made from jowar } \\
\text { flour) }(70 \mathrm{~g})\end{array}$ & $77 \pm 8$ & - \\
\hline Kiwi fruit ${ }^{\mathrm{b}}$ & $47 \pm 4$ & 6 & $\begin{array}{l}\text { Pongal (rice and roasted green gram dal, } \\
\text { pressure cooked), }(250 \mathrm{~g})\end{array}$ & $90 \pm 3$ & 47 \\
\hline $\begin{array}{l}\text { Mango, } \\
\text { ripe }^{\mathrm{d}}\end{array}$ & $60 \pm 16$ & 9 & Poori with potato masala $(150 \mathrm{~g})$ & $82 \pm 2$ & 34 \\
\hline Orange & $45 \pm 4$ & 5 & $\begin{array}{l}\text { Puttu (steamed rice with grated fresh } \\
\text { coconut) with bengal gram curry, }(250 \mathrm{~g})\end{array}$ & $79 \pm 4$ & 58 \\
\hline $\begin{array}{l}\text { Papaya, } \\
\text { ripe }^{\mathrm{d}}\end{array}$ & $60 \pm 16$ & 17 & Upittu $(150 \mathrm{~g})$ & $67 \pm 3$ & 28 \\
\hline Pear & $38 \pm 2$ & 4 & Wholegrain millet, pressure cooked & $68 \pm 8$ & - \\
\hline Pineapple $^{b}$ & 51 & 8 & $\begin{array}{l}\text { Dosa (parboiled and raw rice, soaked, } \\
\text { ground, fermented and fried) with } \\
\text { chutney, }(150 \mathrm{~g})\end{array}$ & $77 \pm 3$ & 30 \\
\hline Raisins & $66 \pm 6$ & 28 & $\begin{array}{l}\text { Idli (parboiled and raw rice }+ \text { black dal, } \\
\text { soaked, ground, fermented, steamed) with } \\
\text { chutney }(250 \mathrm{~g})\end{array}$ & $77 \pm 2$ & 40 \\
\hline $\begin{array}{r}\text { Fructose } \\
(50 \mathrm{~g})\end{array}$ & $20 \pm 5$ & 2 & & & \\
\hline $\begin{array}{l}\text { Sucrose } \\
\qquad(25 \mathrm{~g})^{\mathrm{b}}\end{array}$ & $110 \pm 21$ & 11 & & & \\
\hline
\end{tabular}

The glycemic load is estimated by multiplying the food's listed glycemic index value with glucose as the reference food by the listed $\mathrm{g}$ carbohydrate per serving and dividing by 100

${ }^{a}$ The average serving size was $120 \mathrm{~g}$ for all fresh fruits, $60 \mathrm{~g}$ for dried fruits (apricots, dates and raisins) and $10 \mathrm{~g}$ for fructose and sucrose

b Portions of the test food and reference food contained $25 \mathrm{~g}$ carbohydrate

c Variety: Australian dried dates

${ }^{\mathrm{d}}$ Portions of the test food and reference food contained $75 \mathrm{~g}$ carbohydrates 
Table 5 Diet recall chart

Dietary habit (vegetarian/non-vegetarian/ova-vegetarian)

24-h diet recall-week day

Early morning

Breakfast

Lunch

Tea

Snacks

Dinner

$$
\text { Milk/coffee/tea/green tea }
$$

Idli/dosa/pongal/millet idli/millet dosa/bread/cereal

Chutney/sambhar

Buttermilk/tea/tender coconut water

Broken wheat/millet/rice/chapatti

Vegetable (non-starchy)

Sambhar/dal/chicken/egg

Curd/buttermilk

Tea/coffee/green tea

Fruits/dry fruits/roasted pulses

Roti/dosa/mix lentil dosa/dhokla

Vegetable (non-starchy)

Sambhar/dal/kadi (yoghurt stew)/egg

Curd/buttermilk/milk
$1 \operatorname{cup}(200 \mathrm{ml})$

2 nos/1 cup

3 tsps/ 1 cup

1 cup

2 nos/ 1 cup

2 cups

$1 / 2$ cup/ 1 cup

$1 / 2$ cup/1 cup

1 cup

1 cup/1/4 cup

1 or 2 nos

2 cups

1 cup/1 no

$1 / 2$ cup/1 cup

$1 \operatorname{cup}(200 \mathrm{ml})$

2 nos

2 tsps

1 cup

1 cup

2 cups

$1 / 2$ cup/1 cup

$1 / 2$ cup/1 cup

1 cup

$1 \mathrm{cup} / 1 / 4$ cup

1 or 2 nos

2 cups

1 cup/1 no

$1 / 2 \mathrm{cup} / 1$ cup 
guidance on portion control and regularized eating patterns are common approaches. The choice of food plan depends on the RD's experience guided by evidence-based recommendations and adjusted based on the patient's needs and preferences.

Partial meal replacement (PMR) or full meal replacements (FMR) are other strategies led by RDs for body weight control and reducing body fat and can be used effectively in T2DM [150-152]. These approaches include replacement of one or two daily meals (PMR) or all meals (FMR) with a healthful single food or a combination of foods such as fortified bars, powders, shakes, frozen foods, dietary supplements, etc. These meal plans help maintain dietary adequacy by providing acceptable macronutrient distribution and improving the intake of vitamins, minerals and proteins, thereby reducing the risk of deficiencies that are common in patients on restricted diets. Combining low GI, high-fiber foods such as leafy vegetables (amaranth, fenugreek, spinach, radish leaves, etc.) or nonstarchy vegetables such as tomatoes, gourds, brinjal, cauliflower, etc., is an efficient approach to replacing carbohydrates with fibers and lowering the GI and GL of regular meals [149].

\section{STEP 4: FOLLOW-UP: MONITORING AND EVALUATION}

Review of progress is important to determine the appropriateness of the prescribed diet plan, identify patient fidelity and gauge the success of the current approach. The expert panel recommended that individuals who are prescribed MNT should visit the RD on every visit to the diabetologist, more frequently (3-6 months) during the initial phase of MNT and at least annually on regularization of dietary habits. Diet recall charts are a useful tool to monitor patient's acceptance and commitment to MNT that indicate important dietary-behavioral changes and are essential for long-term adherence to MNT (Table 5). These charts would also help compute nutrition and dietary intakes and make necessary and timely adjustments in case the predefined nutrition therapy goals are not met or to match physiologic improvements. Follow-up sessions with the $\mathrm{RD}$ can be made via face-to-face meetings or telephonically to resolve any queries or problems and continue nutritional counseling and motivation.

\section{CONCLUSION}

MNT is an effective and affordable therapeutic approach that should be made an indispensable component of T2DM prevention and management. It is a complex process, which involves tailoring of diet plans based on the individual's metabolic pathophysiology (prediabetes, early or late $\mathrm{T} 2 \mathrm{DM}$ ) to provide adequate nutrients and calories while accommodating the individual's culinary practices and eating patterns. Appropriate MNT should be devised and monitored by a team of RDs and diabetologists based on their experience and the patient's previous diet history, blood glucose levels and presence of comorbidities to ensure best care. The recommendations and strategies provided in this document should be adopted within the context of current clinical practice and at the discretion of the RDs and diabetologists. Overall, MNT should provide convenient and culturally oriented choices that will motivate individuals to engage in healthful dietary habits.

\section{ACKNOWLEDGEMENTS}

Funding. Signutra Inc. provided funding for the writing and editorial support and also funded the journal's article processing charges and Open Access fee for this article.

\section{Medical Writing and/or Editorial} Assistance. The authors thank Priya Ganpathy, ISMPP CMPP ${ }^{\mathrm{TM}}$, for medical writing assistance and Sangita Patil, PhD, ISMPP CMPP ${ }^{\mathrm{TM}}$ (both SIRO Clinpharm Pvt., Ltd., India), for additional editorial support. The authors also thank Dr. Chetan Mehndiratta, MD, PGDPV (Signutra Inc.), for leading the project. 
Authorship. All named authors meet the International Committee of Medical Journal Editors (ICMJE) criteria for authorship for this manuscript, take responsibility for the integrity of the work as a whole and have given final approval to the version to be published.

Disclosures. Sanjay Kalra is a member of the journal's Editorial Board. Vijay Viswanathan, Dharini Krishnan, Rajeev Chawla, Mangesh Tiwaskar, Banshi Saboo, Manash Baruah, Subhankar Chowdhury, B. M. Makkar and Shalini Jaggi have nothing to disclose.

Compliance with Ethics Guidelines. This article is based on previously conducted studies and does not contain any studies with human participants or animals performed by any of the authors.

Data Availability. Data sharing is not applicable to this article as no data sets were generated or analyzed during the current study.

Open Access. This article is distributed under the terms of the Creative Commons Attribution-NonCommercial 4.0 International License (http://creativecommons.org/licenses/ by-nc/4.0/), which permits any noncommercial use, distribution, and reproduction in any medium, provided you give appropriate credit to the original author(s) and the source, provide a link to the Creative Commons license, and indicate if changes were made.

\section{REFERENCES}

1. Cho NH, Shaw JE, Karuranga S, et al. IDF Diabetes Atlas: global estimates of diabetes prevalence for 2017 and projections for 2045. Diabetes Res Clin Pract. 2018;138:271-81.

2. IDF Diabetes Atlas. Eighth Edition: International Diabetes Federation; 2017 [10 April 2018]. https:// www.diabete.qc.ca/en/understand-diabetes/.../IDFDA-8e-EN-finalR3.pdf. Accessed 10 Apr 2018.

3. Popkin BM. Nutrition transition and the global diabetes epidemic. Curr Diabetes Rep. 2015;15:64.
4. Gopalan C. Rising incidence of obesity, coronary heart disease and diabetes in the Indian urban middle class. Possible role of genetic and environmental factors. World Rev Nutr Diet. 2001;90:127-43.

5. Ramachandran A, Snehalatha C, Dharmaraj D, Viswanathan M. Prevalence of glucose intolerance in Asian Indians. Urban-rural difference and significance of upper body adiposity. Diabetes Care. 1992;15:1348-55.

6. Gopinath N, Chadha SL, Jain P, Shekhawat S, Tandon R. An epidemiological study of obesity in adults in the urban population of Delhi. J Assoc Phys India. 1994;42:212-5.

7. Anjana RM, Deepa M, Pradeepa R, et al. Prevalence of diabetes and prediabetes in 15 states of India: results from the ICMR-INDIAB population-based cross-sectional study. Lancet Diabetes Endocrinol. 2017;5:585-96.

8. Dixit AA, Azar KM, Gardner CD, Palaniappan LP. Incorporation of whole, ancient grains into a modern Asian Indian diet to reduce the burden of chronic disease. Nutr Rev. 2011;69:479-88.

9. Shah VN, Mohan V. Diabetes in India: what is different? Curr Opin Endocrinol Diabetes Obes. 2015;22:283-9.

10. Misra A, Singhal N, Sivakumar B, et al. Nutrition transition in India: secular trends in dietary intake and their relationship to diet-related non-communicable diseases. J Diabetes. 2011;3:278-92.

11. Gulati S, Misra A. Sugar intake, obesity, and diabetes in India. Nutrients. 2014;6:5955-74.

12. Patil R, Nasrin AN, Datta SS, Boratne AV, Lokeshmaran. Popular misconceptions regarding the diabetes management: where should we focus our attention? J Clin Diagn Res. 2013;7:287-91.

13. Sircar AR, Sircar S, Sircar J, Misra S. Patients' concepts and attitudes about diabetes. J Diabetes Complicat. 2010;24:398-403.

14. Tuomilehto J, Lindstrom J, Eriksson JG, et al. Prevention of type 2 diabetes mellitus by changes in lifestyle among subjects with impaired glucose tolerance. N Engl J Med. 2001;344:1343-50.

15. Knowler WC, Barrett-Connor E, Fowler SE, et al. Reduction in the incidence of type 2 diabetes with lifestyle intervention or metformin. N Engl J Med. 2002;346:393-403.

16. Lean ME, Leslie WS, Barnes AC, et al. Primary careled weight management for remission of type 2 
diabetes (DiRECT): an open-label, cluster-randomised trial. Lancet. 2018;391:541-51.

17. Bantle JP, Wylie-Rosett J, Albright AL, et al. Nutrition recommendations and interventions for diabetes: a position statement of the American Diabetes Association. Diabetes Care. 2008;31(Suppl 1):S61-78.

18. Franz MJ, Bantle JP, Beebe CA, et al. Evidence-based nutrition principles and recommendations for the treatment and prevention of diabetes and related complications. Diabetes Care. 2002;25:148-98.

19. Morris SF, Wylie-Rosett J. Medical nutrition therapy: a key to diabetes management and prevention. Clin Diabetes. 2010;28:12-8.

20. Johnson EQ, Valera S. Medical nutrition therapy in non-insulin-dependent diabetes mellitus improves clinical outcome. J Am Diet Assoc. 1995;95:700-1.

21. Delahanty LM, Halford BN. The role of diet behaviors in achieving improved glycemic control in intensively treated patients in the Diabetes Control and Complications Trial. Diabetes Care. 1993;16:1453-8.

22. Eeley EA, Stratton IM, Hadden DR, et al. UKPDS 18: estimated dietary intake in type 2 diabetic patients randomly allocated to diet, sulphonylurea or insulin therapy. Diabet Med. 1996;13:656-62.

23. Kulkarni K, Castle G, Gregory R, et al. Nutrition practice guidelines for type 1 diabetes mellitus positively affect dietitian practices and patient outcomes. The Diabetes Care and Education Dietetic Practice Group. J Am Diet Assoc. 1998;98:62-70 (quiz 1-2).

24. Christensen NK, Steiner J, Whalen J, Pfister R. Contribution of medical nutrition therapy and diabetes self-management education to diabetes control as assessed by hemoglobin A 1c. Diabetes Spectr. 2000;13:72.

25. Carey M, Gillespie S. Position of The American Dietetic Association: cost-effectiveness of medical nutrition therapy. J Acad Nutr Diet. 1995;95:88.

26. Garber AJ, Abrahamson MJ, Barzilay JI, et al. Consensus statement by the American Association of Clinical Endocrinologists and American College of Endocrinology on the comprehensive type 2 diabetes management algorithm-2018 executive summary. Endocr Pract. 2018;24:91-120.

27. Evert AB, Boucher JL, Cypress $\mathrm{M}$, et al. Nutrition therapy recommendations for the management of adults with diabetes. Diabetes Care. 2014;37(Suppl 1):S120-43.
28. Ley SH, Hamdy O, Mohan V, Hu FB. Prevention and management of type 2 diabetes: dietary components and nutritional strategies. Lancet. 2014;383:1999-2007.

29. Madhu S, Saboo B, Makkar BM, et al. RSSDI clinical practice recommendations for management of type 2 diabetes mellitus, 2015. Int J Diabetes Dev Ctries. 2015;35:1-71.

30. Bajaj S. RSSDI clinical practice recommendations for the management of type 2 diabetes mellitus 2017 . Int J Diabetes Dev Ctries. 2018;38:1-115.

31. Evert AB, Boucher JL, Cypress $M$, et al. Nutrition therapy recommendations for the management of adults with diabetes. Diabetes Care. 2013;36:3821-42.

32. American Diabetes Association. 4. Lifestyle management: standards of medical care in diabetes2018. Diabetes Care. 2018;41:S38-50.

33. Davis NJ, Tomuta N, Schechter C, et al. Comparative study of the effects of a 1-year dietary intervention of a low-carbohydrate diet versus a low-fat diet on weight and glycemic control in type 2 diabetes. Diabetes Care. 2009;32:1147-52.

34. Heilbronn LK, Noakes M, Clifton PM. Effect of energy restriction, weight loss, and diet composition on plasma lipids and glucose in patients with type 2 diabetes. Diabetes Care. 1999;22:889-95.

35. ICMR guidelines for management of diabetes II [13 April 2018]. http://icmr.nic.in/guidelines_diabetes/ guide_diabetes.htm. Accessed 11 Apr $201 \overline{8}$.

36. Ramachandran A, Snehalatha C, Kapur A, et al. High prevalence of diabetes and impaired glucose tolerance in India: National Urban Diabetes Survey. Diabetologia. 2001;44:1094-101.

37. Ramachandran A, Snehalatha C, Vijay V. Low risk threshold for acquired diabetogenic factors in Asian Indians. Diabetes Res Clin Pract. 2004;65:189-95.

38. Briggs Early K, Stanley K. Position of the Academy of Nutrition and Dietetics: the role of medical nutrition therapy and registered dietitian nutritionists in the prevention and treatment of prediabetes and type 2 diabetes. J Acad Nutr Diet. 2018;118:343-53.

39. Diabetes Prevention Program Research Group. The Diabetes Prevention Program (DPP): description of lifestyle intervention. Diabetes Care. 2002;25:2165-71.

40. Saaristo T, Moilanen L, Korpi-Hyovalti E, et al. Lifestyle intervention for prevention of type 2 diabetes in primary health care: one-year follow-up of 
the Finnish National Diabetes Prevention Program (FIN-D2D). Diabetes Care. 2010;33:2146-51.

41. Eriksson J, Lindstrom J, Valle T, et al. Prevention of type II diabetes in subjects with impaired glucose tolerance: the Diabetes Prevention Study (DPS) in Finland. Study design and 1-year interim report on the feasibility of the lifestyle intervention programme. Diabetologia. 1999;42:793-801.

42. Lindstrom J, Ilanne-Parikka $\mathrm{P}$, Peltonen $\mathrm{M}$, et al. Sustained reduction in the incidence of type 2 diabetes by lifestyle intervention: follow-up of the Finnish Diabetes Prevention Study. Lancet. 2006;368:1673-9.

43. Diabetes Prevention Program Research Group, Knowler WC, Fowler SE, et al. 10-year follow-up of diabetes incidence and weight loss in the Diabetes Prevention Program Outcomes Study. Lancet. 2009;374:1677-86.

44. Ramachandran A, Snehalatha C, Mary S, et al. The Indian Diabetes Prevention Programme shows that lifestyle modification and metformin prevent type 2 diabetes in Asian Indian subjects with impaired glucose tolerance (IDPP-1). Diabetologia. 2006;49:289-97.

45. Ram J, Selvam S, Snehalatha C, et al. Improvement in diet habits, independent of physical activity helps to reduce incident diabetes among prediabetic Asian Indian men. Diabetes Res Clin Pract. 2014;106:491-5.

46. Balagopal P, Kamalamma N, Patel TG, Misra R. A community-based diabetes prevention and management education program in a rural village in India. Diabetes Care. 2008;31:1097-104.

47. Krishnan A, Ekowati R, Baridalyne N, et al. Evaluation of community-based interventions for noncommunicable diseases: experiences from India and Indonesia. Health Promot Int. 2011;26:276-89.

48. Sathish T, Williams ED, Pasricha N, et al. Cluster randomised controlled trial of a peer-led lifestyle intervention program: study protocol for the Kerala diabetes prevention program. BMC Public Health. 2013;13:1035.

49. Weber MB, Ranjani H, Staimez LR, et al. The stepwise approach to diabetes prevention: results from the D-CLIP randomized controlled trial. Diabetes Care. 2016;39:1760-7.

50. Gulati S, Misra A, Tiwari R, et al. Effect of highprotein meal replacement on weight and cardiometabolic profile in overweight/obese Asian Indians in North India. $\mathrm{Br} \mathrm{J}$ Nutr. 2017; 117:1531-40.
51. Wedick NM, Sudha V, Spiegelman D, et al. Study design and methods for a randomized crossover trial substituting brown rice for white rice on diabetes risk factors in India. Int J Food Sci Nutr. 2015;66:797-804.

52. Blumberg JB, Cena H, Barr SI, et al. The use of multivitamin/multimineral supplements: a modified Delphi consensus panel report. Clin Ther. 2018;40:640-57.

53. Dyson PA, Twenefour D, Breen C, et al. Diabetes UK evidence-based nutrition guidelines for the prevention and management of diabetes. Diabet Med. 2018;35:541-7.

54. Kesavadev J, Saboo B, Sadikot S, et al. Unproven therapies for diabetes and their implications. Adv Ther. 2017;34:60-77.

55. Pi-Sunyer X. The look AHEAD trial: a review and discussion of its outcomes. Curr Nutr Rep. 2014;3:387-91.

56. Myers EF, Trostler N, Varsha V, Voet H. Insights from the Diabetes in India Nutrition Guidelines Study: adopting innovations using a knowledge transfer model. Top Clin Nutr. 2017;32:69-86.

57. Viswanathan M, Mohan V, Ramakrishna A, Snehalatha C, Anderson JW. Long-term experience with high-carbohydrate high-fiber diets in Indian diabetic patients. Diabetol Croat. 1984;13:163-74.

58. Mohan V, Ramachandran A, Viswanathan M. Dietary therapy of diabetes, evaluation of the high carbohydrate high fiber diet therapy. Recent Adv Diabetes. 1983;80:657-63.

59. Gulati PD, Vaishnava H, editors. Effect of high carbohydrate diet on control of diabetes. In: Indian National Congress on Diabetes; 1969.

60. Tripathy BB, Panda NC, Misra A, Nanda S. Studies on insulin response to isocaloric meals of varying composition. J Diabet Assoc India. 1975;14:35.

61. Anderson JW, Ward K. Long-term effects of highcarbohydrate, high-fiber diets on glucose and lipid metabolism: a preliminary report on patients with diabetes. Diabetes Care. 1978;1:77-82.

62. De Natale C, Annuzzi G, Bozzetto L, et al. Effects of a plant-based high-carbohydrate/high-fiber diet versus high-monounsaturated fat/low-carbohydrate diet on postprandial lipids in type 2 diabetic patients. Diabetes Care. 2009;32:2168-73.

63. Sylvetsky AC, Edelstein SL, Walford G, et al. A highcarbohydrate, high-fiber, low-fat diet results in weight loss among adults at high risk of type 2 diabetes. J Nutr. 2017;147:2060-6. 
64. Chandalia M, Garg A, Lutjohann D, et al. Beneficial effects of high dietary fiber intake in patients with type 2 diabetes mellitus. $\mathrm{N}$ Engl J Med. 2000;342:1392-8.

65. Misra A, Khurana L, Isharwal S, Bhardwaj S. South Asian diets and insulin resistance. $\mathrm{Br} \mathrm{J}$ Nutr. 2009;101:465-73.

66. Mohan V, Radhika G, Sathya RM, et al. Dietary carbohydrates, glycaemic load, food groups and newly detected type 2 diabetes among urban Asian Indian population in Chennai, India (Chennai Urban Rural Epidemiology Study 59). Br J Nutr. 2009;102:1498-506.

67. Pande A, Krishnamoorthy G, Moulick ND. Hypoglycaemic and hypolipidaemic effects of low GI and medium GL Indian diets in type 2 diabetics for a period of 4 weeks: a prospective study. Int J Food Sci Nutr. 2012;63:649-58.

68. Boers HM, MacAulay K, Murray P, et al. Efficacy of fibre additions to flatbread flour mixes for reducing post-meal glucose and insulin responses in healthy Indian subjects. Br J Nutr. 2017;117:386-94.

69. Radhika G, Sumathi C, Ganesan A, et al. Glycaemic index of Indian flatbreads (rotis) prepared using whole wheat flour and 'atta mix'-added whole wheat flour. Br J Nutr. 2010;103:1642-7.

70. Thondre PS, Henry CJ. High-molecular-weight barley beta-glucan in chapatis (unleavened Indian flatbread) lowers glycemic index. Nutr Res. 2009;29:480-6.

71. Raizada N, Jyotsna VP, Sreenivas V, Tandon N. Serum vitamin B12 levels in type 2 diabetes patients on metformin compared to those never on metformin: a cross-sectional study. Indian J Endocrinol Metab. 2017;21:424-8.

72. Valdes-Ramos R, Guadarrama-Lopez AL, MartinezCarrillo BE, Benitez-Arciniega AD. Vitamins and type 2 diabetes mellitus. Endocr Metab Immune Disord Drug Targets. 2015;15:54-63.

73. Balk EM, Tatsioni A, Lichtenstein AH, Lau J, Pittas AG. Effect of chromium supplementation on glucose metabolism and lipids: a systematic review of randomized controlled trials. Diabetes Care. 2007;30:2154-63.

74. Gunasekara P, Hettiarachchi M, Liyanage C, Lekamwasam S. Effects of zinc and multimineral vitamin supplementation on glycemic and lipid control in adult diabetes. Diabetes Metab Syndr Obes. 2011;4:53-60.

75. Rodriguez-Moran M, Guerrero-Romero F. Oral magnesium supplementation improves insulin sensitivity and metabolic control in type 2 diabetic subjects: a randomized double-blind controlled trial. Diabetes Care. 2003;26:1147-52.

76. Soric MM, Renner ET, Smith SR. Effect of daily vitamin D supplementation on HbA1c in patients with uncontrolled type 2 diabetes mellitus: a pilot study. J Diabetes. 2012;4:104-5.

77. Korkut D, Ergor G, Kaner G, Kurklu N. The relationship between nutrition knowledge and development of complications in type 2 diabetic patients. Romanian J Diabetes Nutr Metab Dis. 2016;23:341-51.

78. UKPDS Group. UK Prospective Diabetes Study 7: response of fasting plasma glucose to diet therapy in newly presenting type II diabetic patients. Metabolism. 1990;39:905-12.

79. Gau BR, Chen HY, Hung SY, et al. The impact of nutritional status on treatment outcomes of patients with limb-threatening diabetic foot ulcers. J Diabetes Complicat. 2016;30:138-42.

80. Bunner AE, Wells CL, Gonzales J, et al. A dietary intervention for chronic diabetic neuropathy pain: a randomized controlled pilot study. Nutr Diabetes. 2015;5:e158.

81. Danquah I, Bedu-Addo G, Mockenhaupt FP. Type 2 diabetes mellitus and increased risk for malaria infection. Emerg Infect Dis. 2010;16:1601-4.

82. Kalra S, Khandelwal D, Singla R, Aggarwal S, Dutta D. Malaria and diabetes. J Pak Med Assoc. 2017;67:810-3.

83. Nyenwe EA, Jerkins TW, Umpierrez GE, Kitabchi AE. Management of type 2 diabetes: evolving strategies for the treatment of patients with type 2 diabetes. Metabolism. 2011;60:1-23.

84. English E, Idris I, Smith G, et al. The effect of anaemia and abnormalities of erythrocyte indices on HbA1c analysis: a systematic review. Diabetologia. 2015;58:1409-21.

85. Yedla N, Kuchay MS, Mithal A. Hemoglobin E disease and glycosylated hemoglobin. Indian J Endocrinol Metab. 2015;19:683-5.

86. Shankar AH. Nutritional modulation of malaria morbidity and mortality. J Infect Dis. 2000;182(Suppl 1):S37-53.

87. Vucak J, Katic M, Bielen I, et al. Association between hyperuricemia, prediabetes, and prehypertension in the Croatian adult population-a cross-sectional study. BMC Cardiovasc Disord. 2012;12:117. 
88. Kylokas A, Kaukinen K, Huhtala H, et al. Type 1 and type 2 diabetes in celiac disease: prevalence and effect on clinical and histological presentation. BMC Gastroenterol. 2016;16:76.

89. Ramakrishna BS. Celiac disease: can we avert the impending epidemic in India? Indian J Med Res. 2011;133:5-8.

90. Brown K, DeCoffe D, Molcan E, Gibson DL. Dietinduced dysbiosis of the intestinal microbiota and the effects on immunity and disease. Nutrients. 2012;4:1095-119.

91. Ciardullo AV, Brunetti M, Daghio MM, et al. Characteristics of type 2 diabetic patients cared for by general practitioners either with medical nutrition therapy alone or with hypoglycaemic drugs. Diabetes Nutr Metab. 2004;17:120-3.

92. Dehghan M, Mente A, Zhang X, et al. Associations of fats and carbohydrate intake with cardiovascular disease and mortality in 18 countries from five continents (PURE): a prospective cohort study. Lancet. 2017;390:2050-62.

93. Forouhi NG, Krauss RM, Taubes G, Willett W. Dietary fat and cardiometabolic health: evidence, controversies, and consensus for guidance. BMJ. 2018;361:k2139.

94. Del Gobbo LC, Imamura F, Aslibekyan S, et al. Omega-3 polyunsaturated fatty acid biomarkers and coronary heart disease: pooling project of 19 cohort studies. JAMA Intern Med. 2016;176:1155-66.

95. Forouhi NG, Imamura F, Sharp SJ, et al. Association of plasma phospholipid n-3 and n- 6 polyunsaturated fatty acids with type 2 diabetes: the EPIC-InterAct Case-Cohort Study. PLoS Med. 2016;13:e1002094.

96. Garcia-Lopez M, Toledo E, Beunza JJ, et al. Mediterranean diet and heart rate: the PREDIMED randomised trial. Int J Cardiol. 2014;171:299-301.

97. Diaz-Lopez A, Babio N, Martinez-Gonzalez MA, et al. Mediterranean diet, retinopathy, nephropathy, and microvascular diabetes complications: a post hoc analysis of a randomized trial. Diabetes Care. 2015;38:2134-41.

98. Fujii H, Iwase M, Ohkuma T, et al. Impact of dietary fiber intake on glycemic control, cardiovascular risk factors and chronic kidney disease in Japanese patients with type 2 diabetes mellitus: the Fukuoka Diabetes Registry. Nutr J. 2013;12:159.

99. Lie L, Brown L, Forrester TE, et al. The association of dietary fiber intake with cardiometabolic risk in four countries across the epidemiologic transition.
Nutrients. 2018. https://doi.org/10.3390/ nu10050628.

100. Singh RB, Rastogi SS, Rao PV, et al. Diet and lifestyle guidelines and desirable levels of risk factors for the prevention of diabetes and its vascular complications in Indians: a scientific statement of The International College of Nutrition. Indian Consensus Group for the Prevention of Diabetes. J Cardiovasc Risk. 1997;4:201-8.

101. Gulati S, Misra A, Pandey RM. Effect of almond supplementation on glycemia and cardiovascular risk factors in Asian Indians in North India with type 2 diabetes mellitus: a 24-week study. Metab Syndr Relat Disord. 2017;15:98-105.

102. Gulati S, Misra A, Pandey RM. Effects of $3 \mathrm{~g}$ of soluble fiber from oats on lipid levels of Asian Indians-a randomized controlled, parallel arm study. Lipids Health Dis. 2017;16:71.

103. Zeller KR, Jacobson H. Reducing dietary protein intake to retard progression of diabetic nephropathy. Am J Kidney Dis. 1989;13:17-9.

104. Dullaart RP, Beusekamp BJ, Meijer S, van Doormaal JJ, Sluiter WJ. Long-term effects of protein-restricted diet on albuminuria and renal function in IDDM patients without clinical nephropathy and hypertension. Diabetes Care. 1993;16:483-92.

105. Walker JD, Bending JJ, Dodds RA, et al. Restriction of dietary protein and progression of renal failure in diabetic nephropathy. Lancet. 1989;2:1411-5.

106. Mitch WE. Dietary protein restriction in patients with chronic renal failure. Kidney Int. 1991;40: 326-41.

107. Ko GJ, Kalantar-Zadeh K, Goldstein-Fuchs J, Rhee CM. Dietary approaches in the management of diabetic patients with kidney disease. Nutrients. 2017. https://doi.org/10.3390/nu9080824.

108. Pedrini MT, Levey AS, Lau J, Chalmers TC, Wang $\mathrm{PH}$. The effect of dietary protein restriction on the progression of diabetic and nondiabetic renal diseases: a meta-analysis. Ann Intern Med. 1996;124: 627-32.

109. Viswanathan V, Snehalatha C, Varadharini MP, et al. Prevalence of microalbuminuria among vegetarian and non-vegetarian south Indian diabetic patients. Indian J Nephrol. 2002;12:73-6.

110. Dunkler D, Dehghan M, Teo KK, et al. Diet and kidney disease in high-risk individuals with type 2 diabetes mellitus. JAMA Intern Med. 2013;173: 1682-92. 
111. KDOQI. KDOQI clinical practice guidelines and clinical practice recommendations for diabetes and chronic kidney disease. Am J Kidney Dis. 2007;49:S12-154.

112. Whitham D. Nutrition for the prevention and treatment of chronic kidney disease in diabetes. Can J Diabetes. 2014;38:344-8.

113. Shapiro H, Theilla M, Attal-Singer J, Singer P. Effects of polyunsaturated fatty acid consumption in diabetic nephropathy. Nat Rev Nephrol. 2011;7: 110-21.

114. Misra A, Khurana L. The metabolic syndrome in South Asians: epidemiology, determinants, and prevention. Metab Syndr Relat Disord. 2009;7: 497-514.

115. Bakker LE, van Schinkel LD, Guigas B, et al. A 5-day high-fat, high-calorie diet impairs insulin sensitivity in healthy, young South Asian men but not in Caucasian men. Diabetes. 2014;63:248-58.

116. Singhal N, Misra A, Shah P, Gulati S. Effects of controlled school-based multi-component model of nutrition and lifestyle interventions on behavior modification, anthropometry and metabolic risk profile of urban Asian Indian adolescents in North India. Eur J Clin Nutr. 2010;64:364-73.

117. Azadbakht L, Izadi V, Surkan PJ, Esmaillzadeh A. Effect of a high protein weight loss diet on weight, high-sensitivity C-reactive protein, and cardiovascular risk among overweight and obese women: a parallel clinical trial. Int $\mathrm{J}$ Endocrinol. 2013;2013:971724.

118. Neacsu M, Fyfe C, Horgan G, Johnstone AM. Appetite control and biomarkers of satiety with vegetarian (soy) and meat-based high-protein diets for weight loss in obese men: a randomized crossover trial. Am J Clin Nutr. 2014;100:548-58.

119. Samaha FF, Iqbal N, Seshadri P, et al. A low-carbohydrate as compared with a low-fat diet in severe obesity. N Engl J Med. 2003;348:2074-81.

120. Bhatt AA, Choudhari PK, Mahajan RR, et al. Effect of a low-calorie diet on restoration of normoglycemia in obese subjects with type 2 diabetes. Indian J Endocrinol Metab. 2017;21:776-80.

121. Gulati S, Misra A. Abdominal obesity and type 2 diabetes in Asian Indians: dietary strategies including edible oils, cooking practices and sugar intake. Eur J Clin Nutr. 2017;71:850-7.

122. Misra A, Sharma R, Gulati S, et al. Consensus dietary guidelines for healthy living and prevention of obesity, the metabolic syndrome, diabetes, and related disorders in Asian Indians. Diabetes Technol Ther. 2011;13:683-94.

123. American Diabetes Association. Gestational diabetes mellitus. Diabetes Care. 2004;27(Suppl 1):S88-90.

124. Mithal A, Bansal B, Kalra S. Gestational diabetes in India: science and society. Indian $\mathrm{J}$ Endocrinol Metab. 2015;19:701-4.

125. Kayal A, Anjana RM, Mohan V. Gestational diabetes-An update from India, 2013. Diabetes Voice. 2013;58. http://mdrf-eprints.in/860/. Accessed 11 Apr 2018.

126. Shi M, Liu Z-L, Steinmann P, et al. Medical nutrition therapy for pregnant women with gestational diabetes mellitus-a retrospective cohort study. Taiwan J Obstet Gynecol. 2016;55:666-71.

127. Reader DM. Medical nutrition therapy and lifestyle interventions. Diabetes Care. 2007;30:S188-93.

128. American Diabetes Association. 13. Management of diabetes in pregnancy: standards of medical care in diabetes-2018. Diabetes Care. 2018;41:S137-43.

129. Saldana TM, Siega-Riz AM, Adair LS. Effect of macronutrient intake on the development of glucose intolerance during pregnancy. Am J Clin Nutr. 2004;79:479-86.

130. Sahariah SA, Potdar RD, Gandhi M, et al. A daily snack containing green leafy vegetables, fruit and milk before and during pregnancy prevented gestational diabetes in a randomized controlled trial in Mumbai, India. J Nutr. 2016;146:1453S-60S.

131. Bruno R, Petrella E, Bertarini V, et al. Adherence to a lifestyle programme in overweight/obese pregnant women and effect on gestational diabetes mellitus: a randomized controlled trial. Matern Child Nutr. 2017;13:e12333.

132. Gunderson EP. Gestational diabetes and nutritional recommendations. Curr Diabetes Rep. 2004;4: $377-86$.

133. Seshiah V, Sahay BK, Das A, et al. Gestational diabetes mellitus-Indian guidelines. J Indian Med Assoc. 2009;107:799-802, 804-6.

134. Moses RG, Barker M, Winter M, Petocz P, BrandMiller JC. Can a low-glycemic index diet reduce the need for insulin in gestational diabetes mellitus?: a randomized trial. Diabetes Care. 2009;32:996-1000.

135. Hernandez TL. Carbohydrate content in the GDM diet: two views: view 1: nutrition therapy in gestational diabetes: the case for complex carbohydrates. 
Diabetes Spectr Publ Am Diabetes Assoc. 2016;29:82-8.

136. Bethesda M. Gestational diabetes: a practical guide to a healthy pregnancy. Bethesda: National Institutes of Health, National Institutes of Child Health and Human Development; 1993.

137. Blumer I, Hadar E, Hadden DR, et al. Diabetes and pregnancy: an endocrine society clinical practice guideline. J Clin Endocrinol Metab. 2013;98: 4227-49.

138. Magon N, Padmanabhan S, Seshiah V. Medical nutrition therapy in Gestational Diabetes Mellitus. In: Seshiah V, editors. Medical Nutrition Therapy in Gestational Diabetes Mellitus. Contemporary Topics in Gestational Diabetes Mellitus. 2014.

139. Seshiah V. Monitoring and medical nutrition therapy of gestational diabetes mellitus. Med Update. $2011 ; 164-8$.

140. Bhavadharini B, Anjana RM, Deepa M, et al. Gestational weight gain and pregnancy outcomes in relation to body mass index in Asian Indian women. Indian J Endocrinol Metab. 2017;21:58893.

141. Rasmussen KM, Yaktine AL. Weight gain during pregnancy: reexamining the guidelines. Washington, DC; 2009.

142. Kitzmiller JL, Block JM, Brown FM, et al. Managing preexisting diabetes for pregnancy: summary of evidence and consensus recommendations for care. Diabetes Care. 2008;31:1060-79.

143. Reader DM. Medical nutrition therapy and lifestyle interventions. Diabetes Care. 2007;30(Suppl 2): S188-93.

144. Viswanathan Vijay, Bajaj Sarita, Kalra Sanjay, et al. RSSDI clinical practice recommendations for diagnosis, prevention, and control of the diabetes mellitus-tuberculosis double burden. Int J Diabetes Dev Ctries. 2017;37:379-99.
145. World Health Organization. Guideline: nutritional care and support for patients with tuberculosis. Geneva: World Health Organization; 2013.

146. Pastors JG, Warshaw H, Daly A, Franz M, Kulkarni K. The evidence for the effectiveness of medical nutrition therapy in diabetes management. Diabetes Care. 2002;25:608-13.

147. Foster-Powell K, Holt SH, Brand-Miller JC. International table of glycemic index and glycemic load values: 2002. Am J Clin Nutr. 2002;76:5-56.

148. Famakin O, Fatoyinbo A, Ijarotimi OS, Badejo AA, Fagbemi TN. Assessment of nutritional quality, glycaemic index, antidiabetic and sensory properties of plantain (Musa paradisiaca)-based functional dough meals. J Food Sci Technol. 2016;53:3865-75.

149. Hermansen ML, Eriksen NM, Mortensen LS, Holm L, Hermansen K. Can the Glycemic Index (GI) be used as a tool in the prevention and management of type 2 diabetes? Rev Diabet Stud. 2006;3:61-71.

150. Ashley JM, Herzog H, Clodfelter S, et al. Nutrient adequacy during weight loss interventions: a randomized study in women comparing the dietary intake in a meal replacement group with a traditional food group. Nutr J. 2007;6:12.

151. Ryan DH, Espeland MA, Foster GD, et al. Look AHEAD (Action for Health in Diabetes): design and methods for a clinical trial of weight loss for the prevention of cardiovascular disease in type 2 diabetes. Control Clin Trials. 2003;24:610-28.

152. Tovar AR, Caamano Mdel C, Garcia-Padilla S, et al. The inclusion of a partial meal replacement with or without inulin to a calorie restricted diet contributes to reach recommended intakes of micronutrients and decrease plasma triglycerides: a randomized clinical trial in obese Mexican women. Nutr J. 2012;11:44.

153. Atkinson FS, Fostein-Powell K, Brand Miller JC. International tables of glycemic index and glycemic load values 2008. Diabetes Care. 2008;31:2281-3. 